\title{
Market and Regional Segmentation and Risk Premia in the First Era of Financial Globalization*
}

\author{
David Chambers \\ Cambridge University
}

\author{
Sergei Sarkissian \\ McGill University
}

\author{
Michael J. Schill \\ University of Virginia
}

October 16, 2017

\begin{abstract}
* Chambers is from the Judge Business School, Cambridge University. Sarkissian is from the McGill University Faculty of Management, Montreal, and Yerevan State University, Yerevan, Armenia (visiting). Schill is from the Darden Graduate School of Business Administration, University of Virginia. Chambers may be reached at d.chambers@jbs.cam.ac.uk, Sarkissian may be reached at sergei.sarkissian@mcgill.ca, and Schill may be reached at schill@virginia.edu. We appreciate the comments of the Editor (Robin Greenwood), two anonymous Referees, Olivier Accominotti, Effi Benmelech, Ben Chabot, Nicholas Crafts, Elroy Dimson, Marc Flandreau, Carola Frydman, Will Goetzmann, Andrew Karolyi, Piotr Korczak, Tim Kroencke, Naomi Lamoreaux, Larry Neal, Raghu Rau, Peter Rousseau, Oleg Rytchkov, Pedro Saffi, Marc Weidenmier, Eugene White, Mira Wilkins, as well as participants at the 2015 Edinburgh Corporate Finance Conference, the 2016 European Finance Association Meeting in Oslo, the 2013 Northern Finance Association meeting in Quebec City, the 2012 Western Economic Association meeting in San Francisco, the 2012 Economic History Association meeting in Vancouver, the 2015 FMA Napa Conference, the 2015 Cambridge-Princeton Finance Workshop, and seminars at the University of Memphis and University of Virginia. Special thanks go to Lauren Bost, John Garcia, Michael Hiltrop, Olga Ivinskaya, Yunki Kim, Erin Marsh, Susan Norrisey, Danila Pankov, Florence Pei, Emily Schill, Annilyn Spjut, Lars Spjut, Giorgio Vintani, and Matthew Zalar for excellent research assistance. Chambers acknowledges financial support from his Keynes Fellowship, the Newton Centre for Endowment Asset Management and the Cambridge Endowment for Research in Finance, Sarkissian acknowledges financial support from the Social Sciences \& Humanities Research Council of Canada, and Schill acknowledges financial support from the Darden School Foundation. All errors are ours. Send correspondence to Michael Schill, the Darden Graduate School of Business Administration, University of Virginia, Charlottesville, VA 22906, USA; telephone: +1-434-924-4071. E-mail: schill@virginia.edu.
\end{abstract}




\title{
Market and Regional Segmentation and Risk Premia in the First Era of Financial Globalization
}

\begin{abstract}
We study market segmentation effects using data on U.S. railroads that list their bonds in New York and London between 1873 and 1913. This sample provides a unique setting for such analysis because of the precision offered by bond yields in cost of capital estimation, the geography-specific nature of railroad assets, and ongoing substantial technological change. We document a significant reduction in market segmentation over time. Whilst New York bond yields exceeded those in London in the 1870s, this premium disappeared by the early 1900s. However, the segmentation premium persisted in the more remote regions of the United States.
\end{abstract}

JEL Classification: F36; G15; G30; O16

Keywords: Cross-listing; Economic geography; Market integration; Stock exchanges 
Geography has been characterized as playing an important role in capital market development. Distance can create frictions in connecting market participants, including explicit institutional barriers, physical exchange costs, as well as information and monitoring costs (e.g., Coval and Moskowitz, 1999, 2001; Hau, 2001; John, Knyazeva, and Knyazeva, 2011). Such geographyrelated frictions can substantially segment markets, creating a premium on a firm's cost of capital (see Solnik, 1974; Errunza and Losq, 1985; Merton, 1987), even if there are no formal restrictions on financial flows.

The foreign listing decision is a particularly interesting laboratory to explore the relation between geography and finance as it represents a conscious choice by management to position the securities of the firm in a different geography for some benefit. One such potential benefit is that a firm may be able to issue securities at a better price in one market than another by enabling foreign investors, who may face considerable geography-related costs, to invest in the firm's securities and share global risk, thereby reducing the cost of capital for the home firm (Alexander, Eun, and Janakiramanan, 1988; Foerster and Karolyi, 1999). ${ }^{1}$ While foreign listings have been used to measure the effects of market segmentation (Miller, 1999; Foerster and Karolyi, 1999; and Hail and Leuz, 2009), these tests have been criticized for the high estimation error inherent in measuring the cost of equity (Gebhardt, Lee, and Swaminathan, 2001; Gozzi, Levine, and Schmukler, 2008; Sarkissian and Schill, 2009, 2016) and for being confounded with other effects of cross-listing such as gains in legal or financial disclosure (Doidge, Karolyi, and Stulz, 2004, 2007).

In this paper, we assess the market segmentation effects in a way that overcomes the challenges of past work by using a historical sample of U.S. railroad bonds listed in New York and London over the 1873 to 1913 period. We document that the yields of bonds listed in New York

\footnotetext{
${ }^{1}$ Other motives for cross-listing include enhancing product visibility (Mittoo, 1992; Pagano, Roell, and Zechner, 2002; Saudagaran, 1988), improving liquidity (Domowitz, Glen, and Madhavan, 1998; Tinic and West, 1974; Werner and Kleidon, 1996), easing foreign firm acquisitions (Gangon and Karolyi, 2009), improving investor protection (Coffee, 1999, 2002; Doidge, 2004; Doidge, Karolyi, and Stulz, 2004, 2007, 2009; Doidge, Karolyi, Lins, Miller, and Stulz, 2009; Dyck and Zingales, 2004; Hail and Leuz, 2009; Reese and Weisbach, 2002), and familiarity links (Sarkissian and Schill, 2004). Sarkissian and Schill (2009) and King and Segal (2009) show that often cost of capital gains to a foreign listing are transitory.
} 
maintained a premium over those listed in London. Furthermore, we examine the variation in this New York - London premium over time, and across domestic regions. We find that the premium declined over time as markets became less segmented: from $20 \mathrm{bp}$ in the $1870 \mathrm{~s}$ to almost zero by the 1900s. In addition, we find that, during crisis periods, borrowing costs rose for U.S. railroads in both markets but that there is no evidence of a London listing mitigating any crisis-induced increase in yields. In logistic regressions we observe that the magnitude of the yield difference is positively associated with the decision to list in London.

We also compare our U.S. railroad sample to a control sample of British railroads. Whilst bond yields in London were 147 bp higher for U.S. railroads than for British railroads in the 1870s, this yield differential had declined to a statistically insignificant 26 bp by the 1900 s. This yield convergence occurred as British investors increasingly diversified their portfolios overseas including the United States (Edelstein, 1982).

Although we control for variation in relevant firm and bond characteristics of U.S. railroads when estimating the New York - London premium, our results may be contaminated by differences across the two samples. To allay this concern, we construct a sample of matched bond pairs where an identical U.S. railroad bond is traded in both New York and London. An example of such bonds is the Baltimore and Ohio Railroad which in 1898 issued a 50-year 4\% Gold Bond that traded in both markets through the remainder of our sample period. We use the prices for this bond in both London and New York. Our matched sample consists of 69 bond pairs totaling 848 firm years over the period 1875 to 1913 . This sample begins in 1875 because very few matched bonds were traded on both markets before that date. The results from this matched sample confirm our full sample results with a positive New York - London premium for the matched bonds across the whole period and a similar decline to the end of the sample.

One unique feature of our dataset is that railroads are easily defined geographically by the location of their assets and headquarters. We exploit this feature to sort railroads into four U.S. regions (NORTH, CENTRAL, SOUTH, and WEST, see Table 1 for definitions) to investigate regional variation in the cross-market premium. We find that the New York - London premium of 
the matched bonds for firms from the SOUTH and WEST regions was 4 to $7 \mathrm{bp}$ larger than for NORTH and CENTRAL railroads. This cross-regional difference in the New York - London premium remains the same in panel tests when controlling for bond characteristics. Hence, the cost of capital reduction following a London listing was greater for railroads located in the more remote regions of the United States, an effect that diminished little over time. Our explanation for this result is that firms in the SOUTH and WEST regions experienced stronger market segmentation than is the case for firms from the NORTH and CENTRAL regions. The observed market segmentation may be related to the relatively higher information costs faced by investors in screening and monitoring railroads in the more remote regions of the United States. Such information costs are relevant not by themselves but because they hindered the movement of capital that would normalize risk premia between various regions of the United States and London. Furthermore, the overall decline in segmentation effects, which we observe over time, is consistent with a fall in these information costs, for which we provide evidence taken from telecommunication rates.

Our paper touches upon four sets of literature. First, we revisit the task of calculating the cost of capital gains from cross-listing (e.g., Miller, 1999; Foerster and Karolyi, 1999; Doidge, Karolyi, and Stulz, 2004, 2007; and Hail and Leuz, 2009). By using corporate bond yields, our study minimizes the impact of confounding effects present in these previous equity-based studies on cost of capital estimation. Second, we add to the empirical work on the measurement of market segmentation. Bekaert, Harvey, Lundblad, and Siegel $(2007,2011)$ estimate the effects of market segmentation using earnings yield (or its inverse, the $\mathrm{P} / \mathrm{E}$ ratio). Although their approach is similar to ours, any comparison of equity earnings yield measures across countries runs into problems of varying growth rates both across markets and firms, and of different accounting standards for computing earnings. Our measure of segmentation focuses on bond rather than equity yields and avoids many of these problems. Third, our finding that two matched securities trade at different prices in two markets references an extant literature that finds price differences across markets in stocks offering identical cash flows (e.g., Rosenthal and Young, 1990; Froot and Dabora, 1999; 
De Jong, Rosenthal, and Van Dijk, 2009; Gagnon and Karolyi, 2010). We extend this literature by adding an additional example - price differences between cross-listed bonds - and show that bonds with identical cash flow promises can trade at different prices in different markets depending on the degree of market segmentation. Finally, we use a unique setting by examining U.S. railroad cross-listings in London in an earlier period similar to studies of cross-listings of English stocks in Amsterdam in the $18^{\text {th }}$ century (Koudijs, 2015; Neal, 1990) to better understand how capital markets function.

The rest of the paper is organized as follows. Section 1 describes the data. Section 2 estimates the impact of U.S. railroad bond listings in London on the cost of capital. Section 3 analyses a sample of matched railroad bonds listed in both New York and London. It also discusses cross-regional differences in borrowing costs. Section 4 explains the time-series and cross-regional patterns in the cost of capital of U.S. railroads. Section 5 concludes.

\section{Data and Summary Statistics}

\subsection{Sample Motivation}

Our analysis of market segmentation effects focuses on a historical (1873-1913) sample of U.S. railroads for five reasons. First, the pre-World War I period is one of emerging globalization of world capital markets (Rajan and Zingales, 2003). Evidence of this trend is provided in this period by the popularity among U.S. firms of listing their corporate securities in London. ${ }^{2}$ In our sample, the proportion of U.S. railroads with a London bond listing exceeds $50 \%$, suggesting that the tendency to list abroad at that time was much greater than for the well-studied samples from the late $20^{\text {th }}$ and early $21^{\text {st }}$ centuries. ${ }^{3}$ This period of high foreign listing activity among U.S. firms coincides with massive investment in the domestic railroad network. Figure 1 illustrates this

\footnotetext{
${ }^{2}$ Only six railroads were listed in London prior to the Civil War (Adler, 1970: 53, 153). London listings grew rapidly from the 1870s. By 1913, U.S. railroads accounted for half of the aggregate British investor portfolio compared to a 37\% index weight (Goetzmann and Ukhov, 2006: Table XI).

${ }^{3}$ The overall proportion of foreign to domestic bond listings in our sample exceeds 0.5 . In contrast, the fraction of cross-listed stocks among the S\&P 500 index companies was on average only about 0.2 in the second half of the $20^{\text {th }}$ century (see Jiao and Sarkissian, 2015).
} 
network growth through the U.S. railroad maps in 1870, 1880, and 1890. According to Davis and Galman (2001), “...in terms of economic development, the construction of the national railway network was probably the most important event of the last half of the nineteenth century" and required "a massive infusion of capital". The importance of British investors in such funding made the London Stock Exchange the major foreign listing venue for U.S. railroads (Wilkins, 1989: 200201). In addition, the advent of the telegraph sparked a dramatic reduction in transatlantic information transmission costs from the late 1860s. This major technology shock was critical to the integration of the New York and London capital markets over this period (Garbade and Silber, 1978; Hoag, 2006).

Second, unlike today, bonds, not equities, dominated the portfolios of British and other foreign investors in this period (Wilkins, 1989: 191; Chambers and Esteves, 2014). Hence, the higher incidence of bond listings over stock listings in 1873-1913 helps us exploit the greater precision of bond yields over equity costs when estimating the cost of capital. Bond contracts, unlike equities, clearly specify expected cash payments. Cost of debt estimates are more immune to model specification error and risk premium estimation error than cost of equity estimates. Moreover, given the heavy reliance on bond finance throughout the period of our study, debt represents the most important component of the cost of capital.

Third, investor protection laws were equally weak on both sides of the Atlantic during our study period, and listing regulations of the London and New York Stock Exchanges were minimal (Coffee, 2001). ${ }^{4}$ While cross-country differences in financial reporting, legal liability standards, and listing requirements can create large variation in bonding effects when considering cross listings today (Doidge, Karolyi, and Stulz, 2004; Miller and Puthenpurackal, 2002, 2005), such effects are substantially less during our sample period.

\footnotetext{
${ }^{4}$ If anything, New York was tougher in screening listing applications than was London (Michie, 1987: 256-257). Similarly, U.S. investment banks in New York were more active than their British counterparts in London playing the honest broker between U.S. railroads and British investors (Coffee, 2001).
} 
Fourth, product markets have been shown to have important implications for foreign listing (Pagano, Roell, and Zechner, 2002). Yet, there is no concern about the contaminating effects of product market exports in our setting, since railroad assets are geographically defined by nature. A similar argument makes the acquisition facilitation motive irrelevant to our study (Gagnon and Karolyi, 2009).

Fifth, the substantial cross-regional variation in U.S. economic development in this period facilitates our analysis of within-market regional segmentation effects. This variation across regions was driven by the country's vast size, the rise of a manufacturing belt, westward expansion, and the legacy of the Civil War weighing heavily on the economy of the South. The geographically defined nature of railroad assets and their headquarters permits the allocation of our sample firms into defined regions. Employing these regional samples, we investigate the impact of withincountry capital market segmentation on the cost of capital and how this varies over time.

In identifying bonds we focus on the London and New York stock exchanges. The New York Stock Exchange was the most important exchange in the United States through this period and railroads constituted the largest and most heavily traded industry (Michie, 1987: 197). The London Stock Exchange was a substantially larger market and was the most developed stock market in the world at this time. By the end of our sample, London's stock market capitalization to GDP ratio was $450 \%$ compared to $230 \%$ for New York (Hannah, 2015). Railroads also represented the largest listed sector on the London market (Grossman, 2002: Table 1). Whilst today emerging market firms look to cross-list on the world's most developed stock market, New York; in our sample period U.S. firms looked to London for their cross-listing benefits.

\subsection{Sample Construction}

We construct a dataset of U.S. railroad bonds listed on the New York Stock Exchange or the London Stock Exchange between 1873 and 1913. At the time, bonds were listed and traded on the floors of both the New York and London stock exchanges. Both exchanges and their respective financial press published price lists of bonds and stocks which were widely available to investors 
- mainly wealthy individuals. These price lists are published in the Commercial and Financial Chronicle for New York, and the Investors Monthly Manual and the Stock Exchange Daily Official List for London. We require that all sample bonds have security price data included in one or more of these lists. U.S. railroads could achieve a London listing of a bond already listed in New York with or without a prospectus issue in London. In the case of a listing via a prospectus issue, bond prices quoted in the London lists require adjustment to be directly comparable with New York bond prices (Huebner, 1922, 87-98; Nelson, 1904, 53-54). ${ }^{5}$

In addition, we require that sample firms have financial statements in the Poor's Manual of the Railroads of the United States, which is the most comprehensive annual survey of U.S. railroad companies during our sample period. Using the descriptions in the Poor's Manual, we exclude railroads that are headquartered outside of the United States or are subsidiaries of another company. The total number of firms in the sample is 196 which we believe captures the bulk of U.S. railroad assets at the time. As a control sample, we obtain a separate sample of British railroads that are listed in London during the same period. This list is obtained through the Investors Monthly Manual.

We assign each U.S. firm to a particular region based on the location of the firm's headquarters, which is listed in the Poor's Manual usually as the Principal Office. We use region definitions outlined by the Poor's Manual. Naturally, the region definitions change over time as the United States develops geographically. For example, in the 1870s, the Poor's Manual defines the Western region as everything west of and including Ohio. From the late 1880 s onwards, Poor's adopts a static regional definition. We opt to use this later regional classification for our sample, and then aggregate the eight Poor's Manual regions into four broader regions. For example, the

\footnotetext{
${ }^{5}$ London price quotes of dollar-denominated U.S. railroad bonds issued in London by way of a prospectus typically made the exchange rate assumption of $\$ 5.00$ to the pound sterling - the exceptions being before 1878 , when the assumed rate was below $\$ 5.00$ to the pound. To correct for this convention, we adjust the prices of these bonds. The adjustment factor is the ratio of the prevailing dollar/sterling exchange rate to the assumed exchange rate e.g., $\$ 5.00$. Under the de facto gold standard, from the end of 1878 , when the prevailing exchange rate was around $\$ 4.87$, London prices published in the price lists are multiplied by an adjustment factor of 0.975 . Before 1878, when the prevailing exchange rate ranged above $\$ 5.00$, London prices are multiplied by an adjustment factor above one, specifically 1.12 in $1875,1.08$ in 1876 and 1.02 in 1877.
} 
New England and Middle states are combined to form the NORTH region. Table 1 provides the details of the regional classification. Of the 196 railroads, the NORTH, CENTRAL, SOUTH, and WEST regions have 50, 58, 32, and 56 firms, respectively.

Using the security listings in the Investors Monthly Manual, we identify those U.S. railroads that are listed in London. In Table 2, we show a frequency distribution of U.S. railroad bond and common stock listings in New York and London by geographic regions. We observe that bonds were the most common type of security listed for the full sample and across all U.S. regions. Among the 143 railroads quoted on the New York Stock Exchange, 131 listed at least one bond compared to only 90 that listed their common stock. Similarly, among the 117 U.S. railroads quoted on the London Stock Exchange according to the Investors Monthly Manual, all 117 firms listed at least one of their bonds and only 40 listed their common stock. To explore the sequencing of security listing, we give the ratio of firms that listed a bond before a stock in each market in the column entitled "Bond First." In New York, 71\% of the firms listed a bond before their equity, while in London this fraction is 95\%. The focus of this paper is on the bond listings.

Figure 2 reports for each year the number of U.S. railroads with bonds listed in both New York and London, and the number of British railroads with bonds listed in London. The number of U.S. railroads listed in New York increases steadily from 27 in 1873 to a peak of 113 by 1890, then drops over the next decade and slowly declines to 67 listings in 1913. As for U.S. railroads listed in London, their number continues to increase until 1895 with 90 listings, then drops to around 55 listings by the 1900s. Our control sample of British railroads listed in London experiences much less variation with a slow rise from 26 listings in 1873 to 51 listings at the peak in 1901 and 1902, then a decline to 36 by 1913. The end-of-sample decreases in the number of railroads on both exchanges are due largely to consolidating mergers within the industry.

The proportion of U.S. railroads with a London bond listing relative to all railroads listed in both markets varies across region over the sample period. The NORTH railroads retained the highest cross-listing proportion at about 70\%, particularly in the 1870s and 1880s. The CENTRAL railroads had the lowest proportion of bonds listed in London at only $40-50 \%$ throughout the 
sample period. In contrast, the proportion of railroads from SOUTH and WEST with a London bond listing remained below 50\% up until the late 1880 s, with both regions catching up with the NORTH in the 1890 s.

\subsection{Firm and Bond Characteristics}

For each railroad in the sample, we collect data on five firm characteristics from financial statements reported in the Poor's Manual from 1873 to 1913: revenue (Revenue), total assets (Assets), revenue growth (Revenue growth), asset growth (Asset growth), and return on assets (ROA). Revenue is defined as total revenue across all firm operations, and is frequently called 'gross earnings' in the financial statements of the time. Revenue growth (Asset growth) is the total revenue (assets) divided by the lagged revenue (assets) less unity. ROA is the difference between total revenue and total operating expenses divided by lagged total assets. To reduce the impact of outliers, we winsorize the growth rates and ROA at the $1 \%$ and $99 \%$ level. In total, we obtain between 3,601 and 4,157 firm-year observations depending on the availability of particular data items in the Poor's Manuals. For British railroads, we are only able to collect one firm characteristic measure. We define a size measure (assets) as the sum of book debt and equity capital as reported in the Investors Monthly Manual and the Stock Exchange Year Book and convert this value to U.S. dollars at an exchange rate of USD4.87 $=$ GBP1.

Table 3 summarizes the statistics of railroad company characteristics. Panel A reports their frequency and averages for U.S. railroads listed only in New York, U.S. railroads listed only in London, U.S. railroads listed in both New York and London, and British railroads listed in London. The U.S. railroads listed only in London are slightly larger and have lower operating returns than those listed only in New York. The U.S. railroads that listed in both markets have substantially larger revenue and assets. This size bias is consistent with more recent samples of cross-listing firms (see Sarkissian and Schill, 2012). The size of the British railroads appears comparable to that of the average U.S. railroad. In Panel B, we look at cross-regional differences in firm characteristics. The railroads from NORTH are the most profitable $(\mathrm{ROA}=5.5 \%)$ and generate the 
most revenue. Those from WEST lead in growth and asset size which is not surprising due to the region's geographic size and its need for more railroad tracks. The railroads from SOUTH and WEST are the least profitable ( $\mathrm{ROA}=4.2 \%$ and $3.9 \%$, respectively).

To measure cross-market differences in the cost of capital we collect end-of-year bond prices for the sample over the 1873 to 1913 period. New York prices are obtained from the Commercial and Financial Chronicle and London prices from both the Investors Monthly Manual and the Stock Exchange Daily Official List. Prices are quoted including accrued interest, except for New York bonds from 1909 onwards due to a change in the way bond prices are reported in the Commercial and Financial Chronicle. We adjust these prices for accrued interest. Next, we compute annual bond yields by dividing the bond coupon payment by the prevailing end-of-year bond price. Where a railroad had more than one bond listed, we select the bond with the longest maturity such that each firm has only one annual observation. To avoid variation in yields due to variation in maturity, bonds are only included if the bond had at least 10 years to maturity. In order to mitigate liquidity concerns, we exclude bonds where prices are not available in at least six months in the calendar year including the month of December.

Since bond rating agencies did not exist until the end of our study period, we are unable to use the bond credit rating as a control variable. Instead, we control for variation in bond and firm characteristics using the existing bond descriptions in the (London) Stock Exchange Year Books and the Poor's Manuals and firm financial data. As Skeel (2001, p.59) and Tufano (1995) make clear, first mortgage bondholders were regarded as senior claimants in any reorganization. To reduce variation in bond seniority, we exclude any bond that is not a first, consolidated, or general mortgage bond, where the mortgage constituted a senior claim on the track, rolling stock, or other fixed asset of the railroad or its equivalent. Accordingly, we omit second, third, and lower-ranked mortgage bonds as well as any bond where we could not ascertain that the quality of the collateral was equivalent to a first, consolidated, or general mortgage.

The predictable cash flow advantages of bonds when estimating the cost of capital disappear once firms face financial distress. As a first screen, we control for financial distress by 
omitting yield observations above $12 \%$. This screen omits 26 bond-year observations from our sample with yields ranging from $13 \%$ to $78 \%$. This threshold of $12 \%$ while admittedly arbitrary was chosen to remove the obvious outliers in the distribution of yields. We impose an additional credit risk screen by excluding those yield observations that exceed one standard deviation above the annual mean yield. This sample restriction serves to increase our confidence of the unlikeliness that our findings are due to systematic variation in credit risk.

Our final sample of U.S railroad bonds includes 114 firms and 3,003 firm years. This sample is somewhat larger than that used by Benmelech (2009) and Macaulay (1938). ${ }^{6}$ Our sample of British railroad bonds includes 60 firms and 1,609 firm years. We consider several bond characteristic variables. The U.S. dollar was on the gold standard until its suspension during the Civil War and returned to it in $1879 .{ }^{7}$ Nonetheless, some investors preferred the security of bonds paying interest and principal in gold or sterling, rather than in U.S. dollars. ${ }^{8}$ Hence, we employ two indicator variables. The first indicator (Gold) equals unity if the principal and the coupons on the bond were payable in gold, and zero otherwise; the second (Sterling) equals unity if the principal and the coupons on the bond were payable in pounds sterling, and zero otherwise. We also include several other bond characteristics. Default dummy is equal to unity in any year a railroad is in default on its bonds, and zero otherwise. Years-to-Maturity is the years left to bond maturity. For the British railroad sample, the Years-to-Maturity is set at 100 years since virtually all British bonds were issued as perpetual bonds (Coyle and Turner, 2013). Since all the bonds in our sample are secured bonds, we do not include a variable to capture variation in borrowing costs for secured versus unsecured debt. The data on the Gold, Sterling, and Years-to-Maturity variables

\footnotetext{
${ }^{6}$ Benmelech (2009) covers 212 railroads but only 390 firm-year observations in four selected years between 1868 and 1882. Over our study period, the Macaulay (1938) sample comprises 69 railroads. The average bond yield in our sample is $4.8 \%$ and ranges from $3.2 \%$ to $8.9 \%$. These values are comparable to Macaulay's estimated average of $4.5 \%$ ranging between $3.9 \%$ and $8.0 \%$.

${ }^{7}$ Although the U.S. had adopted a bimetallic standard for its currency in 1792, the mint ratio overvalued gold such that by 1849 the United States was on a de facto gold standard. Convertibility was suspended during the Civil War. The dollar de facto returned to the gold standard in 1879 and was exchangeable at a fixed exchange rate of $\$ 4.87 / £ 1$ (Bordo and Rockoff, 1996: 401). In some specifications, we control for this change in regimes by adding a pre-1879 fixed effect, OffGold, and an interaction variable between the OffGold and the Sterling dummy variables.

${ }^{8}$ Currency hedging has been identified as a reason for the issuing of foreign currency denominated debt (see Kedia and Mozumdar, 2003; Henderson, Jegadeesh, and Weisbach, 2006).
} 
are drawn from the (London) Stock Exchange Daily Official Lists, the (London) Stock Exchange Year Books and the Poor's Manuals. We compute the bond yield spread, which equals the bond yield less the prevailing yield on the long-dated British government bond obtained from Coyle and Turner (2013).

Investment banks played an increasingly prominent role in underwriting railroad bond issues in our study period in much the same way that they do for major equity listings today. Underwriting relationships were important in improving access to external finance in the early twentieth century (Simon, 1998, Ramirez, 1995, Frydman and Hilt, 2017). In the absence of comprehensive data on the underwriting relationships for all our railroads across the whole sample period (and not just at the very end of the period) and on bank reputation, our analysis does not take account of such relationships. ${ }^{9}$

Panel B of Table 3 shows the average bond characteristics across U.S. regions over the sample period. Companies from SOUTH and WEST have a larger proportion of their bonds granting investors the right to be paid in gold than those from NORTH and CENTRAL (0.64 and 0.64 versus 0.59 and 0.37 ). This may imply that the insertion of a gold clause was a way of making the SOUTH and WEST bonds more attractive to investors. Reflecting our attempts to cleanse our sample of financial distress, only $1.4 \%$ of bond-year observations experienced a default and with little regional variation. The U.S. bonds have average years to maturity of 46 years, and exhibit relatively little variation across regions. Railroads from NORTH have the lowest average bond yields and, as a result, the lowest spreads over British Government bonds.

\section{Cost of Capital Effects of Bond Listings in London}

\subsection{Preliminary Evidence}

\footnotetext{
${ }^{9}$ As an exploratory test, we run all our tests in the paper with a control for those railroads that had a relation with J.P. Morgan following Ramirez (1995). While unreported due to the incompleteness in the bank relationship variable, we find no evidence of any correlation of our test variables with a Morgan connection.
} 
We start by examining the time-series variation in yield spreads over British government bonds of U.S. railroad bonds traded in the United States and Britain, and of British railroads traded in London. Table 4 shows for each year and decade the mean yield spread of each group. Over the sample period, we observe a decrease in U.S. railroad bond yield spreads from $3.22 \%$ to close to $1.16 \%$. In contrast, British railroad yield spreads exhibit a more modest decline over time from a mean yield spread of $0.95 \%$ down to $0.66 \%$ in the 1900 s (albeit the yield spread is somewhat lower in the middle of the sample period).

Table 4 also shows the difference in mean yield spreads between New York and London listed U.S. bonds (New York - London), between London listed U.S. bonds and British bonds (U.S. - British, London), as well as the statistical significance of this difference in means. The mean yields for U.S. bonds listed in New York were systematically higher than those listed in London. This premium is often statistically and economically significant (particularly at the level of decade aggregation). Second, the premium declined over time. In the 1870 s and 1880 s, the prevailing yield for U.S. railroads listed in New York was larger by 40 and 21 bp, respectively, those of U.S. railroads listed in London. This premium declined to less than $10 \mathrm{bp}$ in the 1890s and 1900s. A comparison between the British and American railroads traded in London shows that British investors in American railroads received a $187 \mathrm{bp}$ premium in the 1870 s that declined to below $30 \mathrm{bp}$ in the last five years of our sample period. The variation in premia across these three samples is consistent with market segmentation effects.

\subsection{Full Sample Tests}

We now examine market segmentation effects more rigorously by controlling for variation in firm and bond characteristics. In our first set of regressions, we test for the impact of a London bond listing on bond yield spreads (Spread) after accounting for both firm and bond characteristics. Accordingly, we construct an indicator variable, FBond $_{i, t}$, which is equal to unity if firm $i$ has a bond listed in London in year $t$, and zero otherwise. Therefore, our regression model is: 


$$
\begin{aligned}
\text { Spread }_{i, t}= & \alpha+\beta \text { BBond }_{i, t-1}+\boldsymbol{\delta} \text { Firm_Char }_{i, t-1}+\boldsymbol{\gamma} \text { Bond }_{-} \text {Char }_{i, t-1}+ \\
& +\lambda \text { Firm_FE }_{-}+\boldsymbol{\theta} \text { Year_F }_{-} E_{t}+e_{i, t}
\end{aligned},
$$

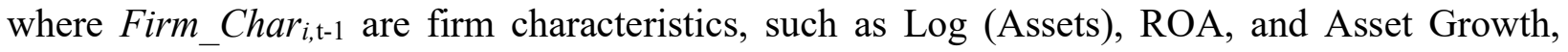
Bond_Char ${ }_{i, \mathrm{t}-1}$ are bond characteristics, such as Gold, Sterling, Default, and Years-to-Maturity. These variables are summarized in Table 3. The last two terms denote firm and time fixed effects. We also include controls for London bonds with end-of-year coupon dates (we define a variable Ex-Day for bonds with coupon dates within a few weeks of the end of the year), as well as the OffGold dummy for the pre-1879 period when the U.S. dollar was not yet fixed against gold.

Table 5 reports our test results using the full sample of U.S. railroads with various specifications. The first specification includes FBond and the four bond-specific variables, as well as year fixed effects. The coefficient on FBond is negative $12 \mathrm{bp}$ and significant, indicating that prevailing yields in London were significantly lower than in New York. Regression (2) adds three firm characteristic controls: Log (Assets), Asset Growth, and ROA. This addition lowers the FBond coefficient slightly to $11 \mathrm{bp}$, and the coefficient retains its high statistical significance. In this regression, the coefficient on Sterling is negative and significant suggesting that bonds with sterling denomination experienced lower yields. The coefficient on Default is positive and significant consistent with bonds of firms that have defaulted maintaining higher yields. The coefficient on Years-to-Maturity is negative, possibly suggesting that longer maturity is associated with better reputation. The firm characteristics of asset size and profitability are negative and significant, implying that bonds issued by larger and more profitable companies maintained lower borrowing costs. The coefficient on Asset Growth is insignificantly different from zero.

Regression (3) adds firm fixed effects to control for any omitted firm characteristics. This inclusion reduces the coefficient on FBond to $6 \mathrm{bp}$, yet retaining its high significance. Regression (4) replaces year fixed effects with a time trend, Time. In this specification, we also estimate the time trend in the New York - London premium by including the interaction term, FBond $\times$ Time. The negative FBond coefficient indicates that the premium starts at $30 \mathrm{bp}$. The positive coefficient 
on the interaction term suggests that this premium declined on average by 0.8 bp per year over the 40 years of the sample. Both coefficients are statistically highly significant.

Given evidence of strong time-series effects, we next consider how the segmentation effects are affected by financial crisis periods. Accordingly, in Regression (5) we add a crisis variable, Crisis, and its interaction with FBond. The crisis variable is taken from the annual default rates for U.S. railroads in Figure 1 by Giesecke, Longstaff, Schaefer, and Strebulaev (2011). It is meant to model the time-varying credit-market conditions in the United States. The positive and significant coefficient associated with the Crisis dummy implies, as expected, that during economic and financial downturns U.S. bond yield spreads increased in both markets. However, we are unable to find evidence that a London bond listing helped in mitigating the negative effects of increased borrowing costs during financial crises (the coefficient on FBond $\times$ Crisis is insignificant). This result is consistent with a study that uses a more recent sample period, which also finds no cost of capital benefit during financial crisis periods for firms cross-listed in the United States (Chandara, Patrob, and Yezegel, 2009). In unreported tests, we find a similar result when replacing our financial crisis variable with an economic crisis variable represented by NBER-defined recession periods.

In Regression (6) of Table 5, we further refine our analysis by including decade fixed effects (1870s, 1880s, 1890s, and 1900s as defined in Table 4) to summarize the time trend. We also continue to include firm fixed effects to control for any omitted firm characteristics. We interact the four decade dummies with FBond to estimate the foreign listing gain in each of these time intervals of the sample. We find that the interaction coefficient for FBond in the 1870 s is negative $20 \mathrm{bp}$, with a t-statistic of 3.21 . The decade coefficients then decline in magnitude to 18 bp in the $1880 \mathrm{~s}$ and $4 \mathrm{bp}$ in the $1890 \mathrm{~s}$. The latter coefficient in the $1900 \mathrm{~s}$ is effectively zero and is not statistically significant. ${ }^{10}$ Thus, our estimations in Table 5 confirm a decline in market

\footnotetext{
${ }^{10} \mathrm{We}$ also tested for the impact of a stock listing on yield spreads, but it did not materially change our results. Furthermore, we consider the possibility that yield spreads might be explained by liquidity in both the London and New York markets. We collect the bid-ask spreads where available for U.S. railroads traded in New York and London
} 
segmentation in that a listing of a U.S. railroad bond in London during our sample period is linked with systematically lower bond yield spreads, and that this difference disappeared over time. ${ }^{11}$

Continuing this same vein of analysis, we examine the magnitude of the gain to British investors from diversifying into U.S. railroad securities from a position in the first half of our study period where their portfolios were dominated by British railroad securities (Mitchell, Chambers and Crafts, 2011). Combining our sample of London-listed U.S. railroad bonds with our control sample of British railroad bonds reported in Tables 3 and 4 above, we run a regression of bond yield spreads on decade dummies and firm and bond characteristics similar to those reported in Table 5 (results not reported). The coefficients on the decade dummies imply that London investors in our sample of U.S. railroad bonds receive an additional $147 \mathrm{bp}$ over the yield prevailing on British railroad bonds and that this premium declined by the $1900 \mathrm{~s}$ to $26 \mathrm{bp}$, statistically insignificant from zero. Based on the point estimates, this implies that the total difference between bond yields on British railroads in London and U.S. railroads in New York is 168 bp $(147$ bp +21 $b p)$ in the $1870 \mathrm{~s}$ and the same $26 \mathrm{bp}(26 \mathrm{bp}+0 \mathrm{bp})$ in the $1900 \mathrm{~s}$. Hence, as the two markets became less segmented and British investors became more diversified, this yield premium disappeared.

\subsection{Determinants of Cross-Listing in London}

A prior literature discusses how capital flows between markets can help normalize risk premia (Stein, 1996; Greenwood, Hanson, and Liao, 2015). Such flows can come not only from the investor side, but also, from the firm side through listings, which "arbitrage" differential risk premia across markets. In other words, the propensity of U.S. firms to list in London might be related to the observed premium of bond yield spreads of New York versus London listed railroads. To examine whether such a relation exists as well as to identify other possible determinants of the

\footnotetext{
in our sample for years 1890 and 1913 from the Commercial and Financial Chronicle and the Stock Exchange Daily Official List respectively. The average spread on U.S. railroads in London is $2.4 \%$ in 1890 and 2.8\% in 1913, whereas that for railroads in New York is $2.0 \%$ in the same two years. These differences are not significant.

${ }^{11}$ Similar estimates of the FBond coefficients in Table 5 are obtained if Log(Assets) and Asset Growth are substituted with Revenue and Revenue Growth.
} 
decision of U.S. railroads to cross-list their bonds in London, we employ the following logistic (logit) regression model:

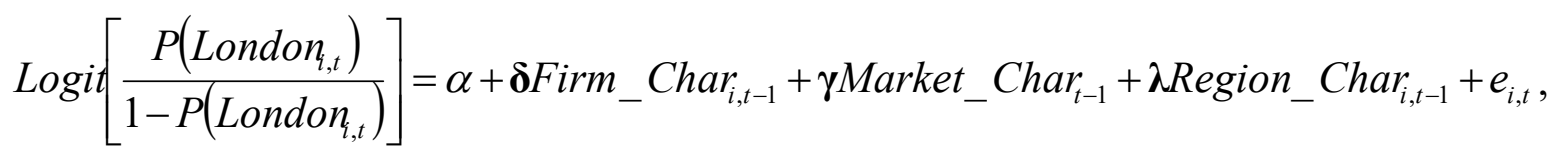

where $P\left(\right.$ London $\left._{i, t}\right)$ is the probability that the dependent indicator variable equals one in year $t$ when railroad $i$ becomes listed in London, and zero otherwise.

Firm_Char ${ }_{i, t}$ is the same set of firm characteristics used in Equation (1). In this case, however, we select only those firm-specific variables where economic intuition suggests that they are likely to be related to foreign listing intensity. They include Asset Growth, ROA, and Default, which are discussed above and summarized in Table 3. We also consider an indicator variable, NYSE_Listing, that takes the value of unity if the firm already had an NYSE bond listing, and zero otherwise.

Market_Char ${ }_{t}$ consists of country and cross-country market characteristics, including the change in the average annual difference in U.S. railroad bond yield spreads between New York and London, $\Delta$ Diff (New York - London), and the change in the average annual difference between the yields of U.S. and British railroad bonds listed in London, $\Delta$ Diff (U.S. - British), both from Table 4, as well as our U.S. Crisis (annual default rates for U.S. railroads) variable. We also account for the change in the ratio of the GDP of the United States to that of the United Kingdom, $\Delta$ GDP(U.S.)/GDP(U.K.). This reflects the relative economic growth of the two countries.

Region_Char ${ }_{i, t}$ has two regional controls. The first one, Region_Track_Growth, is the annual growth rate in total railroad track mileage of the U.S. region where the railroad is located. We suspect that the stronger was growth in the railroad track mileage in a region, the more likely were local capital availability constraints to push firms into considering a foreign financing. The second, SW_1870s, is a dummy variable that equals one for U.S. railroads originating from the SOUTH and WEST regions of the United States in the 1870s, and is zero otherwise. This variable reflects the observation from other researchers that British investors did not start to invest in South 
and South West U.S. railroads until the 1880s (Adler, 1970: 192). All independent variables are lagged by one year.

Table 6 shows the estimation results of our logit regressions. In parentheses, we provide for each coefficient estimate the corresponding Wald chi-square statistic. Regression (1) contains only firm characteristics. We observe that U.S. railroads tended to list in London when asset growth was strong. More interestingly, we also find a negative and significant coefficient on NYSE_Listing implying that a prior listing in the home market is associated with a lower likelihood of a subsequent listing in London. This suggests a possible substitution effect in listing venue that, disregarding other factors, a U.S. listing may on its own have provided sufficient capital raising opportunity for some U.S. railroads and decreased the likelihood of listing abroad.

Regression (2) of Table 6 replaces firm characteristics with market and regional variables. In this estimation, the loadings on $\Delta$ Diff (New York - London) and Region_Track_Growth are both positive and highly significant. The coefficient on the first of these two variables suggests that a larger change in the yield difference between U.S. bonds listed in London and British bonds is associated with an increase in listing activity in London by U.S. firms. This relation is consistent with corporate arbitrage in that U.S. railroads in a search for cheaper debt financing expanded their listing activity in London in response to increasing yield spread difference. The positive coefficient on the second variable implies an increasing likelihood of U.S. railroads from regions experiencing higher regional track mileage growth seeking a London listing to address the greater need for sources of capital outside their local capital market. Finally, the coefficient on SOUTH and WEST railroads in the $1870 \mathrm{~s}, \mathrm{SW} \_1870$ s, is negative and marginally significant, consistent with the claim that British investors preferred not to invest in railroads from these regions in the early years.

In Regressions (3-4) of Table 6, we include all firm, market, and regional controls. Regression (3) does not control for firm fixed effects, while Regression (4) does. The firm fixed effect controls for any omitted firm characteristics related to the firm's propensity to list in London. As before, among firm-specific variables, we find significantly positive coefficients on Asset Growth and a significantly negative coefficient on NYSE_Listing. After controlling for firm fixed 
effects Region_Track_Growth loses its statistical importance but its point estimate declines less dramatically. Among all other market and regional variables, only $\Delta$ Diff (New York - London) retains its sign and high statistical significance.

Overall, we conclude from Table 6 that there is evidence that U.S. firms had the opportunity through cross-listings in London to exploit lower borrowing costs in the United Kingdom. Why then do we not observe U.S. railroads seeking to refinance their entire debt by issuing securities only in the lower cost market? The absence of such wholesale refinancing activity is similar to findings in existing studies showing that firms today do not completely refinance all their debt when faced with borrowing opportunities. ${ }^{12}$ Rather, firms save a few basis points on current funding requirements by restructuring their new borrowing in a particular way. However, such savings are not sufficient to justify refinancing all of their debt. Just as modern firms rarely refinance their entire debt portfolio in response to a market opportunity, debt cost savings available to our sample firms are likely not sufficient to justify the additional costs of switching all debt financing to a foreign market. Thus, U.S. railroad firms used these opportunities simply to fund their current borrowing needs. ${ }^{13}$

\section{The Matched Bond Sample Analysis}

\subsection{Overall Tests}

\footnotetext{
${ }^{12}$ Friedman (1979), Baker, Greenwood, and Wurgler (2003), and Greenwood, Hanson, and Stein (2010) examine the choice between short-term and long-term debt. Faulkender (2005) and Chernenko and Faulkender (2006) consider the choice between fixed and floating-rate debt issuance. Chaplinsky and Ramchand (2004) examine the registration decision of international borrowers with respect to public debt versus Rule 144A debt. Johnson (1988), Allayannis, Brown, and Klapper (2003), Henderson, Jegadeesh, and Weisbach (2006), McBrady and Schill (2007) and McBrady, Mortal, and Schill (2010) look at the choice of currency denomination in bond offerings with respect to exploiting deviations from interest rate parity

${ }^{13}$ The example of the Chesapeake and Ohio (C\&O) Railroad bonds in our sample illustrates the slow-moving nature of corporate arbitrage. Although these bonds do not represent all of the bonds in issue for the C\&O railroad over the sample period, they do represent all of the C\&O bonds in our sample. The first bond is the $6 \% 1911$ bond issued in 1882 in New York. On January 1, 1889, the C\&O railroad issued a 5\% 1939 bond in both London and New York. Although this bond has a lower coupon rate, the $6 \% 1911$ bond remains outstanding to maturity. In 1895 , C\&O issues another bond with a lower coupon rate, the 100-year $19924.5 \%$ bond. This bond is also issued in both London and New York. Despite the lower coupon rate, the existing 5\% 1939 bond continues to remain in C\&O's capital structure. The 4.5\% 1992 bond maintains prices in both London and New York through 1913, the end of the sample. In this example, there is little evidence that $\mathrm{C} \& \mathrm{O}$ is systematically refinancing its entire outstanding funded debt despite lower borrowing rates.
} 
To allay concerns that our full-sample results can be explained by variation in firm or bond characteristics, we repeat our analysis on a matched sample of 69 paired bonds ( 848 bond-year observations), where the same bond was listed in both New York and in London at the same time. This has the advantage of controlling for any systematic variation in risk across the New Yorklisted and London-listed U.S. railroads. The matching process is laborious because the descriptions of the railroad bonds listed in the Commercial and Financial Chronicle (New York) and the Investors Monthly Matching or Stock Exchange Price Lists (London) are abbreviated in different ways and require careful checking in the Poors manuals and the Stock Exchange Year Books to establish a match. Among the 69 paired bonds contained in the matched bond sample, 65 pairs were fungible; the remaining four bonds were sterling-denominated in London and dollardenominated in New York. Unlike for the full sample, we include more than one (paired) bond per railroad. Hence, our matched sample comprises 45 railroads.

Figure 3 graphs the frequency distribution of the number of railroads with a matched bond in each sample year (Plot A) and then the average yield premium of New York-listed over Londonlisted bonds for this matched sub-sample at the end of each year (Plot B). Our analysis starts in 1875, when the number of railroad bonds with a listing on both exchanges reached at least five. This start date is also consistent with the inception date for Wilkins (1989) - the major historical study of foreign investment in U.S. railroads. Figure 3 shows that the premium diminished over time from about $20 \mathrm{bp}$ in the early 1870 s to less than $5 \mathrm{bp}$ in the 1890 s and remained at this low level until the end of the sample period. This time trend is similar to that reported in Table 5. The average premium over the whole sample of matched bonds was $7 \mathrm{bp}-\mathrm{a}$ level consistent with the Fbond coefficient result reported in Table 5 Regression (3).

The evidence from the matched bond sample confirms the important role of market segmentation effects. That is, we show that when investment capital is segmented, cross-market securities can trade at different prices in equilibrium.

\subsection{Regional Tests}


Previous empirical studies suggest that cross-listing benefits for firms from emerging markets are larger than for those from developed markets (e.g., Foerster and Karolyi, 1999; Doidge, Karolyi, and Stulz, 2004). This variation in cross-listing benefits, among other things, may reflect differences in bonding effects, disparities in economic development, and access to capital markets. Our data set provides a unique opportunity to explore this literature due to the geography-specific nature of railroad assets. Unlike most firms where it is difficult to define the geography of the business cleanly, railroad firms own assets and the associated operating revenue attaching to a specific location. For example, during our sample period the Colorado and Southern Railway Company generated all of its operating revenue on lines that were localized in three states in the WEST: Colorado, New Mexico, and Wyoming. At the same time, the Lehigh Valley Railroad Company generated all of its operating revenue on lines that were localized in three states in the NORTH: New Jersey, New York, and Pennsylvania. Across segmented markets, we suspect that the capital market experience might be quite different for those two railroads from two different regions.

Regional differences within the United States during our sample period exist on two main dimensions - economic development and access to capital. The strong regional differences in the economic development are exemplified by the relative poverty of the post-Civil War SOUTH, on the one hand, and the dynamism of the industrialized NORTH and CENTRAL regions, on the other (Mitchener and McLean, 1999; Klein and Crafts, 2012). In addition, access to capital is proxied by the substantially greater distance from the SOUTH and WEST regions to the major financial centers than that of the CENTRAL and NORTH regions. In contrast, there are no obvious cross-regional bonding effects. Such regional differences in economic development and access to capital may manifest themselves in regional segmentation effects. To test for these effects, we examine regional variation in yields using the matched bond sample sorted by region.

Panel A of Table 7 reports the number of matched bond-year observations for each region, as well as the respective means and medians of the matched bond yield spreads for each market in percentage points. Out of 848 observations, 187 belong to NORTH, 207 to CENTRAL, 168 to 
SOUTH, and 286 to WEST. Mean New York yield spreads were lower in NORTH (1.47 percent) and CENTRAL (1.58 percent) than SOUTH (1.90 percent) and WEST (1.94 percent). The panel also reports yield premia by region, defined as the difference between the mean New York and London yield spreads of the matched bonds with their corresponding t-statistics. While the average bond yield spreads in New York were higher than in London for railroads in each region, the difference in bond yield spreads varied across regions as seen in average differences of $1 \mathrm{bp}, 2 \mathrm{bp}$, $6 \mathrm{bp}$, and $8 \mathrm{bp}$ for NORTH, CENTRAL, SOUTH, and WEST, respectively. These premia are suggestive of the regional segmentation effects we expect with smaller yield premia for bonds of railroads from the NORTH and CENTRAL regions (1-2 bp) compared to larger premia in the SOUTH and WEST regions (6-8 bp). In other words, the railroads from more remote regions of the United States benefitted more from a bond listing in London than did railroads from the more developed regions by 4 to $7 \mathrm{bp}$.

Panel B of Table 7 shows how the yield spreads and premia varied over three sample period decades: the 1880s (1879-1890), the 1890s (1891-1900), and the 1900s (1901-1913). The last column presents for each region a test of the difference in the mean yield premium for the 1900s compared to that for the 1880 s and its t-statistic. The panel reveals two important patterns. First, when we decompose the overall downward trend in the premium observed in Figure 3 Plot B, the magnitude of the decline varies by region. We find that there was only a very small decline in the premium in SOUTH from $7 \mathrm{bp}$ to $5 \mathrm{bp}$. The decline in WEST was larger from $11 \mathrm{bps}$ to $7 \mathrm{bp}$, but it is statistically insignificant. On the other hand, the premium in NORTH dropped by 8 bp from 9 bp to $1 \mathrm{bp}(\mathrm{t}$-stat $=3.79)$ and in CENTRAL by $5 \mathrm{bp}$ from $6 \mathrm{bp}$ to $1 \mathrm{bp}(\mathrm{t}$-stat $=2.90)$.

Second, when we compare the decade differences in premium with the NORTH we note that the effects were more pronounced for the SOUTH and WEST railroads than for the CENTRAL railroads. In the 1880s, 1890s, and 1900s, the difference between CENTRAL and NORTH was almost zero and is statistically insignificant. In comparison, the differences between the premia for NORTH railroads and those for SOUTH and WEST railroads were much more pronounced in the last decade of the sample than the first. These results imply both cross-sectional 
and time-series variation in the cost of capital across U.S. regions over our sample period with firms from the less developed SOUTH and WEST regions on average enjoying larger gains from foreign listing than those experienced by firms in the more developed NORTH and CENTRAL regions. Over time this cross-sectional variation increased. While the gains from London listing for firms from SOUTH and WEST declined marginally, they remained significant; in contrast, those for firms in NORTH and CENTRAL disappeared towards the end of our sample period.

To examine the regional segmentation effects more robustly, we turn to a full panel regression setting. Table 8 reports the test results. The dependent variable is the difference in the bond yield spread between New York and London for every year in which we are able to match a bond. We define three indicator variables for three of the regions CENTRAL, SOUTH, and WEST such that the benchmark region for the coefficients on these variables is the NORTH region. Regression (1) includes two bond control variables: Years-to-Maturity and Default that are included to capture any systematic variation in cross-market premia that could be due to variation in how bond characteristics are priced. In this specification, the coefficient estimates of the SOUTH and WEST regional indicators are positive and highly significant with an estimate of 3 bp for the SOUTH and 5 bp for the WEST. This confirms a much larger average yield premium for railroads from the SOUTH or WEST compared to those from NORTH. In Regression (2), we include a time variable and interaction terms between the time dummy and each of the three regional dummies. The coefficient on Time is negative and significant, implying a strong decline in the premia for the NORTH railroad bonds over time. The interactions of the time dummy and the regional dummies generate statistically insignificant coefficients for CENTRAL and WEST, suggesting a general trend for premia to decline in those two regions as well. However, a positive and significant value on SOUTH $\times$ Time implies that premium in this region did not decline in line with the other three regions.

The first two regressions in Table 8 provide substantial support for the notion that the New York - London premium varies directly with the regional remoteness of a railroad from these two markets. To test this conjecture directly, in Regressions (3-4), we replace our four regional 
dummies with a continuous firm-level distance variable (Distance), defined as the distance between the Principal Office of each railroad and New York City in thousands of miles. We find a positive and highly significant coefficient on Distance. Its point estimate signifies that for every 1,000 miles the main office of a railroad was more distant from New York, the greater was the New York - London premium by about 2.8 bp. In Regression (4), we also interact Distance with Time and find that the coefficient on this term is negative and highly significant. This confirms that over our study period the cost of capital gains attributable to a London listing became less sensitive to the distance of the railroad's principal office from New York.

\section{Explaining the Results}

In our tests, we observe two distinct patterns in the financial benefits accruing to U.S. railroad companies from a cross-listing in London during the 1873-1913 period. The first is the time-series trend that shows a decrease in bond yield spreads across all exchanges and a substantial reduction in the yield premium associated with a listing in New York as opposed to London. The second is the cross-regional difference in borrowing costs. How might we explain these market segmentation effects? We see two possible explanations: time-series and cross-regional variation in arbitrage costs or information costs.

Arbitrage costs have been proposed as the source of differential prices in other contexts. Our finding that two matched securities trade at different prices in different markets is similar to an existing literature that documents price differences across markets in securities offering identical cash flows. For example, Rosenthal and Young (1990), Froot and Dabora (1999), and De Jong, Rosenthal, and Van Dijk (2009) find such effects among Siamese twin stocks and Gagnon and Karolyi (2010) find such effects among cross-listed stocks. These authors suggest that price differences are explained by such cross-market factors as arbitrage cost frictions, investor sentiment, and portfolio constraints. We extend this literature by adding an additional example price differences among cross-listed bonds. We show that bonds with identical cash flow promises can trade at different prices in different markets for sustained periods of time. 
Although we do not explicitly test for this, our observed bond yield differences may also be explained by the time series and cross-sectional variation in arbitrage costs. Since our matched bond sample is fungible (with the exception of only four bonds), and these bonds could be traded in either market, the average New York - London yield premium of $4.7 \mathrm{bp}$ across the whole sample period (Table 7, Panel A) could capture the costs of arbitrage between the two locations.

Historians have testified to the importance of transatlantic arbitrage in forcing convergence of New York and London bond yields, particularly in the second half of our sample period. Whilst arbitrage operations began to develop after the transatlantic cable was established in 1866 (Michie, 1987: 187-9), the extent of arbitrage activity was modest and concentrated on the most actively traded U.S. railroad stocks. As communication improved, arbitrage became less risky. By 1900, there were a dozen firms engaged in transatlantic arbitrage, increasing to twenty by 1913 (Huebner, 1922: 87). This increase in arbitrage activity appears consistent with our data. First, the mean difference in New York - London bond yields settled down at around 0 to 5 bp from the late 1890s (Tables 4 and 5 or Figure 3). Second, the decline in the mean difference of the matched (and fungible) bond sample from $7.6 \mathrm{bp}$ in the $1880 \mathrm{~s}$ to $3.6 \mathrm{bp}$ in the 1900 s (Table 7 , Panel B) could also reflect falling arbitrage costs over time.

Following Merton (1987), changes in information costs can also explain the observed patterns in cross-listing effects. In our historical setting, we suggest two possible proxies for information cost: the cross-sectional and time-series variation in telegraph communication and immigration rates from the United Kingdom to the United States. Importantly, telegraph lines were constructed along railroad tracks (Thompson, 1947). Figure 4 shows the telegraph communication rates between London and selected centers of our four U.S. regions: New York for NORTH, Chicago for CENTRAL, the average of Atlanta and New Orleans for SOUTH, and San Francisco for WEST, between 1870 and 1913. The rates represent the cost of transmitting the first 10 words of a message. The source data for London to New York is from the Historical Statistics of the United States: Colonial Times to 1970 Part 2, U.S. Department of Commerce, 1975, based on documents from the U.S. Federal Communications Commission and other sources specified in the 
report. The rates from New York to Chicago and San Francisco, as well as the equally-weighted average of the rates from New York to Atlanta and New Orleans are from Honsowetz (2014). The rates from London to Chicago, San Francisco, and Atlanta/New Orleans are estimated by adding the London - New York rate to the rate between the destination city and New York. Data points between some observations are interpolated.

The decline in telegraph rates graphed in Figure 4 is dramatic and highlights the extent of the communication technology shock during this period. This decline coincides relatively closely with the reduction in the New York - London bond yield difference over our sample period. We observe that the majority of the decline in both the premium and telegraph communication rates occurred in the first half of our sample period. This relation between the premium and communication costs is consistent with the increasing market integration between the United States and the United Kingdom during this time period, even though some studies find substantial integration between these two markets before the Civil War (Sylla, Wilson, and Wright, 2006).

As the costs of information transmission between the United States and London fell, Figure 4 also shows that a clear ordering of the relative costs across the four U.S. regions, reflecting geographic distance from Britain, was preserved. The cheapest rate was to New York, while the most expensive was to San Francisco. The implication is that it was cheaper for British investors to access information regarding their investments in railroads from the more proximate NORTH and CENTRAL regions than from the relatively distant SOUTH and especially WEST regions. These differential information costs also affect the relative costs of arbitrage between the two markets across regions.

The regional variation in information costs may also reflect variation in cultural ties between Britain and these four regions of the United States. Cultural factors may be related to financial and economic outcomes. For instance, Grinblatt, and Keloharju (2001) find the existence of cultural and language preferences in investors' portfolio holdings. Moreover, Algan and Cahuc (2010) show a causal effect of trust on economic growth using the inherited trust of descendants of U.S. immigrants as a measure of inherited trust in their country of origin. We propose that those 
U.S. regions with a larger number of British immigrants were more likely to enjoy stronger ties to their home country, other things equal. Indeed, using the immigration information from the census data of the Integrated Public Use Microdata Series (IPUMS) at the University of Minnesota, we find that NORTH was the region most settled by British immigrants and CENTRAL was the second most settled. ${ }^{14}$ The suggestion then is that the stronger cultural linkages of the NORTH and CENTRAL regions with the United Kingdom could help ameliorate any information gaps for British investors.

The impact of geographic distance and cultural ties on information costs is reinforced by that of economic distance. There were large economic disparities across the four main regions of the United States during this time period. At one extreme, income per capita in the SOUTH remained at only half the national average; at the other, the NORTH and CENTRAL regional economies together constituted the economically important manufacturing belt of the United States. Concepts in economic geography have been employed to understand how it is that industrial activity becomes heavily concentrated and flourishes in a single region (Krugman, 1991; Dougal, Parsons, and Titman, 2015). The manufacturing belt is a prime example of such a regional concentration. In 1900, it accounted for four-fifths of U.S. industrial output despite covering only one-sixth of the national land area (Klein and Crafts, 2012). All but two of the 18 states constituting the belt were in the NORTH and CENTRAL regions. ${ }^{15}$ Hence, these two regions possessed enormous economic power in that period, which in turn had a direct effect on the strength of their trade relations with the United Kingdom. Sarkissian and Schill (2004) argue that in an international setting economic and industrial closeness between markets plays a large role in cross-country investments along with geographic distance.

In sum, the differences in information costs between U.S. regions and the United Kingdom during our sample period were driven by geographic, cultural, and economic factors. Hence,

\footnotetext{
${ }^{14}$ In 1870, British immigrants settling in each of NORTH, CENTRAL, WEST and SOUTH regions as a proportion of all British immigrants into the United States were 50,29, 16 and 5 percent respectively.

${ }^{15}$ The other two states were in the SOUTH (Virginia and West Virginia) and none were in the WEST regions (Klein and Crafts, 2012).
} 
relatively higher communication costs, weaker cultural ties, as well as weaker economic and trade links of the SOUTH and WEST regions with the United Kingdom compared to the NORTH and CENTRAL regions most likely contributed to higher information costs faced by British investors in U.S. railroads listed in New York from SOUTH and WEST. These frictions in turn explain the relatively larger segmentation effects upon the railroads from the SOUTH and WEST regions evidenced by their observed larger New York - London bond yield premia. Since British investors faced larger frictions trading SOUTH and WEST region securities in New York, they were willing to pay more for the diversification benefits which arose when railroad securities from these remote regions listed in London. Over time, as information costs and the accompanying segmentation effects diminished for the less remote areas of the United States, the premia for NORTH and CENTRAL railroad bonds decreased practically to zero. In contrast, due to the higher segmentation of SOUTH and WEST from London, the premium for railroad bonds from those regions remained sizable, albeit decreasing somewhat in the case of the relatively faster developing WEST region.

Although we are not able to definitively identify the channel that is at the root of the New York - London yield premium, we provide some circumstantial evidence that is consistent with either an arbitrage cost or information cost explanation. The full explanation may include a combination of the two.

\section{Conclusions}

Markets can be segmented by a variety of factors, including geography and transaction costs. We study segmentation between the United States and the United Kingdom in a bond market setting over several decades prior to the World War I. We find significant time-series and crossregional differences in the impact of foreign bond listing activity on corporate borrowing costs between 1873 and 1913 for a sample of U.S. firms. Our results are consistent with Merton (1987). We observe substantial foreign listing activity in London among U.S. railroads from all regions that peaked around 1900, with bonds being the preferred security for foreign placements. New 
York-listed U.S. railroads exhibited a bond yield premium compared to London-listed U.S. railroads of $20 \mathrm{bp}$ in the 1870s. Over the subsequent 40 years this premium declined to effectively zero. This decline is consistent with a substantial reduction in market segmentation between the United States and the United Kingdom over this period. We do not find that a London cross-listing was of much help to U.S. railroads in mitigating the cost of capital impact of the frequent financial crises in this period.

Our results show that those U.S. railroads that access British investors via a London listing benefitted from a lower cost of capital in the first part of our sample period and this benefit disappeared over time. Furthermore, this benefit evolved differently over time across regions. The NORTH and CENTRAL regions delivered a larger decline in their premia compared to the SOUTH and WEST regions as time passed. In fact, by the 1900s the premia practically disappeared for the NORTH and CENTRAL railroad bonds. We suggest that this regional variation in the gains from cross-listing was related to differences in information costs between railroads and British investors driven by the geographic, economic, and cultural distances from Britain. We also accept that arbitrage costs provide an alternative channel for explaining these results. Our findings illustrate in a novel historical setting how the decline in market segmentation of two of the world's major capital markets over a century ago provided cost of capital gains to United States railroad firms, particularly in the most developed regions, as well as portfolio diversification opportunities to London investors.

\section{References:}

Adler, D.R., 1970, British Investment in American Railways 1834-98, University of Virginia Press.

Algan, Y., and P. Cahuc, 2010. Inherited Trust and Growth. American Economic Review 100, 2060-2092.

Alexander, G., C. Eun, and S. Janakiramanan, 1988. International Listings and Stock Returns: Some Empirical Evidence. Journal of Financial and Quantitative Analysis 23, 135-151. 
Allayannis, G., G.W. Brown, and L.F. Klapper, 2003. Capital Structure and Financial Risk: Evidence from Foreign Debt Use in East Asia, The Journal of Finance 58, 2667-2709.

Baker, M., R. Greenwood, and J. Wurgler, 2003. The Maturity of Debt issues and Predictable Variation in Bond Returns. Journal of Financial Economics 70, 261-291.

Benmelech, E., 2009. Asset Salability and Debt Maturity: Evidence from Nineteenth-Century American railroads. Review of Financial Studies 22, 1545-1584.

Bekaert, G., C. Harvey, C. Lundblad, and S. Siegel, 2007. Global Growth Opportunities and Market Integration. Journal of Finance 62:1081-1137.

Bekaert, G., C. Harvey, C. Lundblad, and S. Siegel. 2011, What Segments Equity Markets? Review of Financial Studies 24, 3841-3890.

Bordo, M.D. and H. Rockoff, 1996. The Gold Standard as a "Good housekeeping Seal of Approval. Journal of Economic History, 56, 389-428.

Chambers, D., and R. Esteves, 2014. The First Global Emerging Markets Investor: Foreign and Colonial Investment Trust 1880-1913. Explorations in Economic History, 52,1-21.

Chandara, N., D. Patrob, and A. Yezegel, 2009. Crises, Contagion and Cross-Listings. Journal of Banking \& Finance 33, 1709-1729.

Chaplinsky, S., and L. Ramchand, 2004. The Impact of SEC Rule 144A on Corporate Debt Issuance by International Firms, Journal of Business 77, 1073-1098.

Chernenko, S. and M. Faulkender, 2006. Why are Firms Using Interest Rate Swaps to Time the Yield Curve? Working paper, Washington University, St. Louis.

Coffee, J.C., 1999. The Future as History: The Prospects for Global Convergence in Corporate Governance and its Implications. Northwestern Law Review 93, 641-708.

Coffee, J.C., 2001. The Rise of Dispersed Ownership: The Role of Law in the Separation of Ownership and Control. The Yale Law Journal 111, 1-82. 
Coffee, J.C., 2002, Racing Towards the Top? The Impact of Cross-Listings and Stock Market Competition on International Corporate Governance, Working paper, Columbia University.

Coval, J.D., and T.J. Moskowitz, 1999. Home Bias at Home: Local Equity Preference in Domestic Portfolios, Journal of Finance 54, 2045-2073.

Coval, J., and T. J. Moskowitz, 2001. The Geography of Investment: Informed Trading and Asset Prices. Journal of Political Economy 109, 811-841.

Coyle, C., and J. Turner, 2013. Law, Politics and Financial Development: The Great Reversal of the U.K. Corporate Debt Market. Journal of Economic History 73, 810-846.

Davis, L., and R. Gallman, 2001. Evolving Financial Markets and International Capital Flows: Britain, the Americas, and Australia, 1865-1914. London: Routledge.

De Jong, A., L. Rosenthal, and M. Van Dijk, 2009. The Risk and Return of Arbitrage in DualListed Companies. Review of Finance 13, 495-520.

Doidge, C., 2004. U.S. Cross-Listings and the Private Benefits of Control: Evidence from Dual Class Firms. Journal of Financial Economics 72, 519-553.

Doidge, C., G.A. Karolyi, and R. Stulz, 2004. Why are Foreign Firms Listed in the U.S. Worth More? Journal of Financial Economics 71, 205-238.

Doidge, C., G.A. Karolyi, and R. Stulz, 2007. Why do Countries Matter So Much for Corporate governance? Journal of Financial Economics 86, 1-39.

Doidge, C., G.A. Karolyi, and R. Stulz, 2009. Why has New York Become Less Competitive than London in Global Markets? Evaluating Foreign Listing Choices Over Time. Journal of Financial Economics 91, 253-277.

Doidge, C., G.A. Karolyi, K. Lins, D. Miller, and R. Stulz, 2009. Private Benefits of Control, Ownership, and the Cross-Listing Decision. Journal of Finance 64, 425-466. 
Domowitz, I., J. Glen, and A. Madhavan, 1998. International Cross-Listing and Order Flow Migration: Evidence from an Emerging Market. Journal of Finance 53, 2001-2027.

Dougal, C., C.A. Parsons, and S. Titman, 2015. Urban Vibrancy and Corporate Growth. Journal of Finance 70, 163-210.

Dyck, A., L. Zingales, 2004. Private Benefits of Control: An International Comparison. Journal of Finance 59, 533-596.

Edelstein, M., 1982. Overseas Investment in the Age of High Imperialism: The U.K., 1850-1914. Columbia University Press.

Errunza, V., and E. Losq, 1985. International Asset Pricing Under Mild Segmentation: Theory and Tests. Journal of Finance 40, 105-124.

Faulkender, M., 2005. Hedging or Market Timing? Selecting the Interest Rate Exposure of Corporate Debt. Journal of Finance 60, 931-962.

Foerster, S., and G.A. Karolyi, 1999. The Effects of Market Segmentation and Investor Recognition on Asset Prices: Evidence from Foreign Stocks Listing in the United States, Journal of Finance 54. 981-1013.

Friedman, B.M., 1979. Substitution and Expectation Effects of Long-Term Borrowing Behavior and Long-Term Interest Rates. Journal of Money, Credit, and Banking 11, 131-150.

Frydman, C. and E. Hilt, 2017. Investment Banks as Corporate Monitors in the Early $20^{\text {th }}$ Century. American Economic Review 107, 1938-70.

Froot, K., and E. Dabora, 1999. How are stock prices affected by the location of trade? Journal of Financial Economics 53, 189-216.

Gagnon, L., and G.A. Karolyi, 2009. Information, Trading Volume, and International Stock Return Comovements: Evidence from Cross-Listed Stocks. Journal of Financial and Quantitative Analysis 44, 953-986. 
Gagnon, L., and G.A. Karolyi, 2010. Multi-Market Trading and Arbitrage. Journal of Financial Economics 97, 53-80.

Garbade, K.D., and W.L. Silber, 1978. Technology, Communication and the Performance of Financial Markets: 1840-1975. Journal of Finance 33, 819-832.

Gebhardt, W.R., C.M.C. Lee, and B. Swaminathan, 2001. Toward an Implied Cost of Capital. Journal of Accounting Research 39, 135-176.

Giesecke, K., F. Longstaff, S. Schaefer, and I. Strebulaev, 2011. Corporate Default Risk: a 150Year Perspective. Journal of Financial Economics 102, 233-250.

Grinblatt, M., and M. Keloharju, 2001. Distance, Language, and Culture Bias: The Role of Investor Sophistication. Journal of Finance 56, 1053-1073.

Goetzmann, W.N., and A.D. Ukhov, 2006. British Investment Overseas, 1870-1913: A Modern portfolio theory approach. Review of Finance 10, 261-200.

Gozzi, J., R. Levine, and S. Schmukler, 2008. Internationalization and the Evolution of Corporate Valuation. Journal of Financial Economics 88, 607-632.

Greenwood, R., S. Hanson, and G. Liao, 2015. Price Dynamics in Partially Segmented Markets. Working Paper, Harvard University.

Greenwood, R., S. Hanson, and J.C. Stein, 2010. A Gap-Filling Theory of Corporate debt Maturity Choice. Journal of Finance 65, 993-1028.

Grossman, R., 2002. New Indices of British Equity Prices, 1870-1914. Journal of Economic History 62, 121-146.

Hail, L., and C. Leuz, 2009. International Differences in Cost of Capital: Do Legal Institutions and Securities Regulation Matter? Journal of Accounting Research 44, 485-531.

Hannah, L., 2015. A Global Corporate Census: Publicly Traded and Closed Companies in 1910. Economic History Review, 68, 548-573. 
Hau, H., 2001, Location Matters: An Examination of Trading Profits, Journal of Finance 56, 19591983.

Henderson, B., N. Jegadeesh, and M. Weisbach, 2006. World Markets for Raising New Capital. Journal of Financial Economics 82, 63-101.

Hoag, C., 2006. The Atlantic Telegraph Cable and Capital Market Information Flows. Journal of Economic History 66, 342-53.

Honsowetz, A., 2014. Federal Preemption and Competition in the post-1866 United States Telegraph Market. Working paper, Cambridge University.

Huebner, S.S., 1922. The Stock Market. D. Appleton and Company.

Jiao, F., and S. Sarkissian, 2015. Global Liquidity Provision and Risk Sharing. Working paper, McGill University.

John, K., A. Knyazeva, and D. Knyazeva, 2011. Does Geography Matter? Firm Location and Corporate Payout Policy. Journal of Financial Economics 101, 533-551.

Johnson, D., 1988, The Currency Denomination of Long-Term Debt in the Canadian Corporate Sector: An Empirical Analysis, Journal of International Money and Finance 7, 77-90.

Kedia, S., and A. Mozumdar, 2003. Foreign Currency-Denominated Debt: An Empirical Examination. Journal of Business 76, 521-546.

King, M., and D. Segal, 2009. The Long-Term Effects of Cross-Listing, Investor Recognition, and Ownership Structure on Valuation. Review of Financial Studies 22, 2393-2422.

Koudijs, P., 2016. The Boats That Did Not Sail: Asset Price Volatility in a Natural Experiment. Journal of Finance 71, 1185-1226.

Klein, A., and N. Crafts, 2012. Making Sense of the Manufacturing Belt: Determinants of U.S. Industrial Location, 1880-1920. Journal of Economic Geography 12, 775-807. 
Krugman, P., 1991. Increasing Returns and Economic Geography. Journal of Political Economy 99, 483-499.

Macaulay, F., 1938. The movements of interest rates. Bond yields and stock prices in the United States since 1856. National Bureau of Economic Research.

McBrady, M., and M.J. Schill, 2007. Foreign Currency Denominated Borrowing in the Absence of Operating Incentives. Journal of Financial Economics 86, 145-177.

McBrady, M. R., S. Mortal, and M. J. Schill, 2010. Do Firms Believe in Interest Rate Parity? Review of Finance 14, 695-726.

Merton, R., 1987. Presidential address: A Simple Model of Capital Market Equilibrium with Incomplete Information. Journal of Finance 42, 483-510.

Michie, R., 1987. The London and New York Stock Exchanges, 1850-1914. London: Allen \& Unwin.

Mitchell, B., D. Chambers and N. Crafts, 2011. How Good was the Profitability of British Railway, 1870-1912? Economic History Review, 64, 798-831.

Miller, D., 1999. The Market Reaction to International Cross-Listings: Evidence from Depository Receipts. Journal of Financial Economics 51, 10-123.

Miller, D., and J. Puthenpurackal, 2002. The Costs, Determinants, and Wealth Effects of International Capital Raising: Evidence from Public Yankee Bonds. Journal of Financial Intermediation 11, 455-485.

Miller, D., and J. Puthenpurackal, 2005. Security Fungibility and the Cost of Capital: Evidence from Global Bonds. Journal of Financial and Quantitative Analysis 40, 849-872.

Mitchener, K., and I. McLean, 1999. U.S. Regional Growth and Convergence. Journal of Economic History 59, 1016-1042. 
Mittoo, U., 1992. Managerial Perceptions of the Net Benefits of Foreign Listings: Canadian Evidence. Journal of International Financial Management and Accounting 4, 40-62.

Neal, L., 1990. The Rise of Financial Capitalism: International Capital Markets in the Age of Reason, Cambridge University Press.

Nelson, S.A., 1904. The A B C of Options and Arbitrage. Wall Street Library.

Pagano, M., A. Roell, and J. Zechner, 2002. The Geography of Equity Listing: Why do European Companies List Abroad? Journal of Finance 57, 2651-2694.

Rajan, R., and L. Zingales, 2003. The Great Reversals: The Politics of Financial Development in the Twentieth Century. Journal of Financial Economics 69, 5-50.

Ramirez, C.D., 1995. Did J.P. Morgan's Men Add Liquidity? Corporate Investment, Cash Flow, and Financial Structure at the Turn of the Twentieth Century. Journal of Finance 50, 661-678.

Reese, W., and M. Weisbach, 2002. Protection of Minority Shareholder Interests, Cross-Listings in the United States, and Subsequent Equity Offerings. Journal of Financial Economics 66, 65-104.

Rosenthal, L., and C. Young, 1990. The Seemingly Anomalous Price Behavior of Royal Dutch/Shell and Unilever N.V./PLC. Journal of Financial Economics 26, 123-142.

Sarkissian S., and M.J. Schill, 2004. The Overseas Listing Decision: New Evidence of Proximity Preference. Review of Financial Studies 17, 769-809.

Sarkissian S., and M.J. Schill, 2009. Are There Permanent Valuation Gains to Overseas Listing? Review of Financial Studies 22, 371-412.

Sarkissian, S., and M.J. Schill, 2012. The Nature of the Foreign Listing Premium: A Cross-Country Examination. Journal of Banking \& Finance 36, 2494-2511

Sarkissian, S., and M.J. Schill, 2016. Cross-Listing Waves. Journal of Financial and Quantitative Analysis 51, 259-306. 
Saudagaran, S., 1988. An Empirical Study of Selected Factors Influencing the Decision to List on Foreign Stock Exchanges. Journal of International Business Studies 19, 101-127.

Simon M.C., 1998. The Rise and Fall of Bank Control in the United States: 1890-1920. American Economic Review 88, 1077-1093.

Skeel, D., 2001. Debt's Dominion: A History of Bankruptcy Law in America. Princeton University Press.

Solnik, B., 1974. An Equilibrium Model of the International Capital Market. Journal of Economic Theory 18, 365-378.

Stein, J., 1996. Rational Capital Budgeting in an Irrational World. Journal of Business 69, 429455.

Sylla, R., J.W. Wilson, and R.E. Wright, 2006. Integration of Trans-Atlantic Capital Markets, 1790-1845. Review of Finance 10, 613-644.

Thompson, R., 1947. Wiring a Continent: the History of the Telegraph Industry in the United States, 1832-1866. Princeton University Press.

Tinic, S., and R. West, 1974. Marketability of Common Stocks in Canada and the USA: A Comparison of Agent versus Dealer Dominated Markets. Journal of Finance 29, 729-746.

Tufano, P., 1995. Business Failure, Judicial Intervention, and Financial Innovation: Restructuring U.S. Railroads in the Nineteenth Century. Business History Review 71, 1-40.

Werner, I., and A. Kleidon, 1996. U.S. and U.K. Trading of British Cross-Listed stocks: An Intraday Analysis of Market Integration. Review of Financial Studies 9, 619-664.

Wilkins, M., 1989. The History of Foreign Investment in the United States to 1914. Harvard University Press. 
Table 1

Classification of U.S. regions

\begin{tabular}{ll}
\hline Region Name & Constituent States \\
\hline $\begin{array}{l}\text { NORTH: } \\
\text { New England } \\
\text { Middle }\end{array}$ & $\begin{array}{l}\text { Connecticut, Maine, Massachusetts, New Hampshire, Rhode Island, Vermont } \\
\text { Delaware, Maryland, New Jersey, New York, Pennsylvania }\end{array}$ \\
$\begin{array}{l}\text { CENTRAL: } \\
\text { Central Northern }\end{array}$ & Illinois, Indiana, Michigan, Ohio, Wisconsin \\
SOUTH: & Florida, Georgia, North Carolina, South Carolina, Virginia, West Virginia \\
South Atlantic & Alabama, Kentucky, Louisiana, Mississippi, Tennessee \\
Gulf \& Mississippi Valley & \\
WEST: & Iowa, Minnesota, Montana, Nebraska, North Dakota, South Dakota, Wyoming \\
Northwestern & Arkansas, Colorado, Kansas, Missouri, New Mexico, Oklahoma, Texas \\
Southwestern & Arizona, California, Idaho, Nevada, Oregon, Utah, Washington \\
Pacific &
\end{tabular}

This table classifies all U.S. states into four U.S. regions using regional designations of the Poor's Manuals. Railroad companies are allocated to a region based on the location of principal offices. 
Table 2

Frequency distribution of U.S. railroad listings

\begin{tabular}{|c|c|c|c|c|c|c|c|c|c|}
\hline & \multirow[b]{2}{*}{ Total Firms } & \multicolumn{4}{|c|}{ New York Listings } & \multicolumn{4}{|c|}{ London Foreign Listings } \\
\hline & & Firms & Bond & Stock & Bond First & Firms & Bond & Stock & Bond First \\
\hline NORTH & 50 & 35 & 28 & 26 & 0.49 & 31 & 31 & 9 & 0.94 \\
\hline CENTRAL & 58 & 46 & 43 & 27 & 0.65 & 30 & 30 & 11 & 0.90 \\
\hline SOUTH & 32 & 20 & 19 & 13 & 0.90 & 21 & 21 & 5 & 0.95 \\
\hline WEST & 56 & 42 & 41 & 24 & 0.86 & 35 & 35 & 16 & 1.00 \\
\hline Total & 196 & 143 & 131 & 90 & 0.71 & 117 & 117 & 41 & 0.95 \\
\hline
\end{tabular}

This table provides a frequency distribution of the types of securities listings for a sample of U.S. railroads on the New York and London Stock Exchanges from 1873 to 1913. The sample is defined as all U.S. railroads with a bond or ordinary stock listing in New York or London based on the Commercial and Financial Chronicle and the Investors Monthly Manual. The regions are defined in Table 1. We assign each railroad to a region based on the location of its Principal Office. Bond First denotes the proportion of firms which listed bonds in the respective market prior to equities. 
Table 3

Summary statistics of characteristics of U.S. and British railroads

Panel A: Sample characteristics for U.S. and British railroads by listing location

\begin{tabular}{|c|c|c|c|c|c|c|c|c|}
\hline & \multicolumn{6}{|c|}{ U.S. Railroads } & & \\
\hline & \multicolumn{2}{|c|}{ New York only } & \multicolumn{2}{|c|}{ London only } & \multicolumn{2}{|c|}{ New York / London } & \multicolumn{2}{|c|}{ British Railroads } \\
\hline & Obs. & Mean & Obs. & Mean & Obs. & Mean & Obs. & Mean \\
\hline Revenue & 1,594 & 4.13 & 535 & 5.23 & 1,556 & 20.4 & & \\
\hline Assets & 1,504 & 31.5 & 499 & 49.16 & 1,518 & 143.8 & 1,498 & 92.1 \\
\hline Revenue growth & 1,491 & 0.072 & 487 & 0.106 & 1,511 & 0.075 & & \\
\hline Asset growth & 1,400 & 0.042 & 449 & 0.045 & 1,471 & 0.045 & & \\
\hline ROA & 1,415 & 0.046 & 458 & 0.036 & 1,475 & 0.051 & & \\
\hline
\end{tabular}

Panel B: Sample characteristics for U.S. railroads by region

\begin{tabular}{|c|c|c|c|c|c|c|}
\hline & \multirow[b]{2}{*}{ Obs. } & \multicolumn{5}{|c|}{ Mean } \\
\hline & & All & NORTH & CENTRAL & SOUTH & WEST \\
\hline \multicolumn{7}{|c|}{ Firm characteristics: } \\
\hline Revenue & 4,157 & 10.24 & 13.52 & 9.08 & 7.25 & 10.29 \\
\hline Assets & 3,881 & 77.6 & 89.51 & 60.9 & 59.5 & 94.2 \\
\hline Revenue growth & 3,876 & 0.085 & 0.068 & 0.075 & 0.088 & 0.107 \\
\hline Asset growth & 3,601 & 0.049 & 0.039 & 0.046 & 0.060 & 0.054 \\
\hline ROA & 3,640 & 0.047 & 0.055 & 0.050 & 0.042 & 0.039 \\
\hline \multicolumn{7}{|c|}{ Bond characteristics: } \\
\hline Gold & 3,003 & 0.55 & 0.59 & 0.37 & 0.64 & 0.65 \\
\hline Sterling & 3,003 & 0.11 & 0.19 & 0.08 & 0.06 & 0.08 \\
\hline Default & 3,003 & 0.013 & 0.021 & 0.010 & 0.004 & 0.014 \\
\hline Years-to-Maturity & 3,003 & 46.0 & 48.3 & 40.2 & 51.5 & 46.8 \\
\hline Yield & 3,003 & 4.81 & 4.64 & 4.88 & 4.87 & 4.87 \\
\hline Spread & 3,003 & 1.91 & 1.73 & 1.98 & 1.97 & 1.97 \\
\hline
\end{tabular}




\section{Table 3 (continued)}

This table provides summary statistics for the sample of U.S. and British railroads from 1873 to 1913. Panel A and B give the summaries across U.S. stock exchanges and across regions respectively. The regions are defined in Table 1. The variables are defined as follows: Revenue is the total revenue reported in the Poor's Manuals in millions of U.S. dollars. Assets is the total assets in millions of U.S. dollars. ROA is the difference of total revenue and operating expenses divided by the total assets. Revenue (Asset) Growth is, respectively, the current total revenue (assets) divided by the lagged revenue (assets) less unity. Gold is an indicator variable, which equals to unity if the bond is redeemable for gold, and zero otherwise. Sterling is an indicator variable, which equals to unity if the bond is denominated in pounds sterling, and zero otherwise. Default is an indicator variable which equals to unity in any year when a railroad is in default on its bonds according to the Stock Exchange Year Book and zero otherwise. Years-to-Maturity is equal to the number of years until the bond is stated to mature, as indicated by the price source or Poor's Manual. Gold, Sterling, and Years-to-Maturity are taken from descriptions in the source documents. Yield refers to the current yield defined as the coupon payment divided by the prevailing end of year bond price. Yields are adjusted for accrued interest for New York bonds from 1909. Spread is the yield less the prevailing yield on the long-dated British government bond. For British railroads, assets are reported as the total of book debt and equity capital and converted to U.S. dollars at an exchange rate of USD4.87 = GBP1. British railroads typically issued perpetual bonds, therefore, following Coyle and Turner (2013), Years-to-Maturity is defined as 100 years for all British bonds. 
Table 4

Characteristics of U.S. and British railroad bond yield spreads across listing exchanges, 1873-1913

\begin{tabular}{|c|c|c|c|c|c|c|c|c|}
\hline & \multicolumn{5}{|c|}{ U.S. Railroads } & & & \\
\hline & \multicolumn{2}{|c|}{ New York } & \multicolumn{2}{|c|}{ London } & \multirow[b]{2}{*}{ New York - London } & \multicolumn{3}{|c|}{ British Railroads } \\
\hline & Obs. & Mean & Obs. & Mean & & Obs. & Mean & U.S. - British, London \\
\hline 1873 & 16 & 4.03 & 12 & 3.57 & 0.45 & 26 & 0.89 & $2.68^{* * *}$ \\
\hline 1874 & 18 & 3.56 & 13 & 2.85 & $0.72^{* * *}$ & 26 & 0.90 & $1.95^{* * *}$ \\
\hline 1875 & 18 & 3.39 & 15 & 2.80 & $0.59^{* *}$ & 27 & 0.99 & $1.81^{* * *}$ \\
\hline 1876 & 18 & 3.35 & 16 & 2.97 & 0.37 & 26 & 1.03 & $1.94^{* * *}$ \\
\hline 1877 & 21 & 3.37 & 15 & 3.05 & 0.32 & 26 & 1.07 & $1.98^{* * *}$ \\
\hline 1878 & 21 & 3.10 & 19 & 3.04 & 0.06 & 26 & 1.05 & $1.99^{* * *}$ \\
\hline 1879 & 22 & 2.92 & 21 & 2.53 & $0.39^{*}$ & 27 & 0.89 & $1.64^{* * *}$ \\
\hline 1880 & 31 & 2.64 & 23 & 2.25 & $0.39^{*}$ & 27 & 0.79 & $1.45^{* * *}$ \\
\hline $1873-1880$ & 165 & 3.22 & 134 & 2.82 & $0.40^{* * * *}$ & 211 & 0.95 & $1.87^{* * * *}$ \\
\hline 1881 & 27 & 2.51 & 26 & 2.23 & 0.28 & 30 & 0.76 & $1.47^{* * *}$ \\
\hline 1882 & 33 & 2.70 & 24 & 2.27 & $0.43^{* *}$ & 33 & 0.79 & $1.48^{* * *}$ \\
\hline 1883 & 34 & 2.65 & 28 & 2.29 & $0.36^{*}$ & 37 & 0.82 & $1.48^{* * *}$ \\
\hline 1884 & 35 & 2.71 & 31 & 2.40 & 0.32 & 39 & 0.72 & $1.68^{* * *}$ \\
\hline 1885 & 39 & 2.36 & 29 & 2.05 & $0.31^{*}$ & 39 & 0.74 & $1.31^{* * *}$ \\
\hline 1886 & 41 & 2.21 & 33 & 1.94 & 0.27 & 39 & 0.71 & $1.23^{* * *}$ \\
\hline 1887 & 40 & 2.27 & 34 & 2.04 & 0.23 & 39 & 0.69 & $1.35^{* * *}$ \\
\hline 1888 & 51 & 2.09 & 44 & 2.02 & 0.07 & 39 & 0.47 & $1.55^{* * *}$ \\
\hline 1889 & 57 & 2.16 & 46 & 2.11 & 0.05 & 35 & 0.51 & $1.60^{* * *}$ \\
\hline 1890 & 52 & 2.22 & 48 & 2.18 & 0.04 & 41 & 0.50 & $1.73^{* * *}$ \\
\hline $1881-1890$ & 409 & 2.35 & 343 & 2.14 & $0.21^{* * * *}$ & 371 & 0.67 & $1.48^{* * *}$ \\
\hline 1891 & 57 & 2.11 & 48 & 2.09 & 0.02 & 42 & 0.46 & $1.63^{* * *}$ \\
\hline 1892 & 54 & 2.06 & 52 & 2.07 & -0.01 & 44 & 0.45 & $1.62^{* * *}$ \\
\hline 1893 & 51 & 2.31 & 58 & 2.34 & -0.03 & 43 & 0.41 & $1.91^{* * *}$ \\
\hline 1894 & 52 & 2.39 & 57 & 2.21 & 0.18 & 42 & 0.32 & $1.90^{* * *}$ \\
\hline 1895 & 50 & 2.22 & 55 & 2.11 & 0.10 & 43 & 0.26 & $1.85^{* * *}$ \\
\hline 1896 & 46 & 2.39 & 59 & 2.35 & 0.04 & 45 & 0.31 & $2.04^{* * *}$ \\
\hline 1897 & 47 & 2.24 & 54 & 2.16 & 0.09 & 48 & 0.37 & $1.78^{* * *}$ \\
\hline 1898 & 44 & 1.89 & 52 & 1.80 & 0.09 & 48 & 0.48 & $1.31^{* * *}$ \\
\hline 1899 & 44 & 1.57 & 51 & 1.52 & 0.05 & 48 & 0.37 & $1.12^{* * *}$ \\
\hline 1900 & 48 & 1.31 & 44 & 1.15 & 0.15 & 48 & 0.43 & $0.73^{* * *}$ \\
\hline $1891-1900$ & 493 & 2.06 & 530 & 2.01 & 0.05 & 451 & 0.39 & $1.61^{* * *}$ \\
\hline 1901 & 38 & 1.08 & 43 & 1.00 & 0.08 & 51 & 0.42 & $0.59^{* * *}$ \\
\hline 1902 & 40 & 1.14 & 42 & 1.00 & 0.13 & 51 & 0.42 & $0.57^{* * *}$ \\
\hline 1903 & 38 & 1.35 & 37 & 1.22 & 0.12 & 49 & 0.69 & $0.52^{* * *}$ \\
\hline 1904 & 38 & 1.19 & 39 & 1.11 & 0.08 & 48 & 0.65 & $0.46^{* * *}$ \\
\hline 1905 & 37 & 1.26 & 39 & 1.14 & 0.12 & 46 & 0.69 & $0.44^{* * *}$ \\
\hline 1906 & 35 & 1.23 & 37 & 1.14 & 0.10 & 45 & 0.68 & $0.46^{* * *}$ \\
\hline 1907 & 31 & 1.37 & 38 & 1.27 & 0.09 & 44 & 0.72 & $0.56^{* * *}$ \\
\hline 1908 & 35 & 1.18 & 37 & 1.11 & 0.07 & 43 & 0.76 & $0.35^{* * *}$ \\
\hline 1909 & 37 & 1.18 & 35 & 1.07 & 0.11 & 42 & 0.78 & $0.29^{* * *}$ \\
\hline 1910 & 32 & 1.06 & 33 & 0.97 & 0.09 & 41 & 0.73 & $0.24^{* * *}$ \\
\hline 1911 & 34 & 0.98 & 33 & 0.91 & 0.08 & 41 & 0.67 & $0.24^{* * *}$ \\
\hline 1912 & 34 & 0.99 & 34 & 0.95 & 0.04 & 39 & 0.69 & $0.26^{* * *}$ \\
\hline 1913 & 32 & 1.07 & 33 & 1.02 & 0.04 & 36 & 0.76 & $0.27^{* * * *}$ \\
\hline $1901-1913$ & 461 & 1.16 & 480 & 1.07 & $0.09^{* * *}$ & 576 & 0.66 & $0.41^{* * *}$ \\
\hline
\end{tabular}




\section{Table 4 (continued)}

This table summarizes average bond yield spreads over the long dated British government bond of U.S. and British railroads for each year between 1873 and 1913. Yield refers to the current yield defined as the coupon payment divided by the prevailing end of year bond price. "New York - London" is the difference between the mean yield for U.S. firms listed in New York less the mean yield for U.S. firms listed in London. "U.S. - British, London" is the difference between the mean yield for U.S. firms listed in London less the mean yield for U.K. firms listed in London. Where a railroad has more than one bond listed, we select the bond with the longest maturity. The U.S. regions are defined in Table $1 .^{*},{ }^{* *}$, and ${ }^{* * *}$ denote statistical significance at the $10 \%, 5 \%$, and $1 \%$ level, respectively. 
Table 5

Aggregate regression estimates: All U.S. railroad bond yield spreads

\begin{tabular}{|c|c|c|c|c|c|c|}
\hline & (1) & (2) & (3) & (4) & $(5)$ & $(6)$ \\
\hline FBond & $\begin{array}{l}-0.116^{* * *} \\
(5.73)\end{array}$ & $\begin{array}{l}-0.111^{* * *} \\
(5.52)\end{array}$ & $\begin{array}{l}-0.056^{* * *} \\
(3.37)\end{array}$ & $\begin{array}{l}-0.297^{* * *} \\
(4.59)\end{array}$ & $\begin{array}{l}-0.304^{* * *} \\
(4.02)\end{array}$ & \\
\hline FBond_1870s & & & & & & $\begin{array}{l}-0.203^{* * *} \\
(3.21)\end{array}$ \\
\hline FBond_1880s & & & & & & $\begin{array}{l}-0.180^{* * *} \\
(6.01)\end{array}$ \\
\hline FBond_1890s & & & & & & $\begin{array}{l}-0.040 \\
(1.54)\end{array}$ \\
\hline FBond_1900s & & & & & & $\begin{array}{l}0.006 \\
(0.26)\end{array}$ \\
\hline Gold & $\begin{array}{l}0.078^{* * *} \\
(3.74)\end{array}$ & $\begin{array}{l}0.070^{* * *} \\
(3.29)\end{array}$ & $\begin{array}{l}-0.031 \\
(1.39)\end{array}$ & $\begin{array}{l}-0.050^{*} \\
(1.82)\end{array}$ & $\begin{array}{l}-0.047^{*} \\
(1.75)\end{array}$ & $\begin{array}{l}-0.028 \\
(1.23)\end{array}$ \\
\hline Sterling & $\begin{array}{l}-0.166^{* * *} \\
(4.85)\end{array}$ & $\begin{array}{l}-0.196^{* * *} \\
(4.99)\end{array}$ & $\begin{array}{l}-0.126^{* * *} \\
(3.59)\end{array}$ & $\begin{array}{l}-0.091^{* *} \\
(2.03)\end{array}$ & $\begin{array}{l}-0.081^{*} \\
(1.85)\end{array}$ & $\begin{array}{l}-0.063^{*} \\
(1.71)\end{array}$ \\
\hline Default & $\begin{array}{l}0.257^{* * *} \\
(3.46)\end{array}$ & $\begin{array}{l}0.288^{* * *} \\
(3.74)\end{array}$ & $\begin{array}{l}0.078 \\
(1.28)\end{array}$ & $\begin{array}{l}0.209^{* * *} \\
(2.89)\end{array}$ & $\begin{array}{l}0.118^{*} \\
(1.66)\end{array}$ & $\begin{array}{l}0.080 \\
(1.33)\end{array}$ \\
\hline Years-to-Maturity & $\begin{array}{l}-0.005^{* * *} \\
(12.87)\end{array}$ & $\begin{array}{l}-0.003^{* * *} \\
(7.32)\end{array}$ & $\begin{array}{l}-0.007^{* * *} \\
(16.39)\end{array}$ & $\begin{array}{l}-0.007^{* * *} \\
(12.41)\end{array}$ & $\begin{array}{l}-0.007^{* * *} \\
(13.01)\end{array}$ & $\begin{array}{l}-0.007^{* * *} \\
(16.50)\end{array}$ \\
\hline Log (Assets) & & $\begin{array}{l}-0.109^{* * *} \\
(12.15)\end{array}$ & $\begin{array}{l}-0.088^{* * *} \\
(3.30)\end{array}$ & $\begin{array}{l}-0.111^{* * *} \\
(3.45)\end{array}$ & $\begin{array}{l}-0.127^{* * *} \\
(4.02)\end{array}$ & $\begin{array}{l}-0.097^{* * *} \\
(3.64)\end{array}$ \\
\hline Asset Growth & & $\begin{array}{l}0.021 \\
(0.37)\end{array}$ & $\begin{array}{l}-0.055 \\
(1.23)\end{array}$ & $\begin{array}{l}-0.078 \\
(1.46)\end{array}$ & $\begin{array}{l}-0.096^{*} \\
(1.85)\end{array}$ & $\begin{array}{l}-0.058 \\
(1.31)\end{array}$ \\
\hline ROA & & $\begin{array}{l}-4.107^{* * *} \\
(11.54)\end{array}$ & $\begin{array}{l}-2.336^{* * *} \\
(5.38)\end{array}$ & $\begin{array}{l}-4.550^{* * *} \\
(9.27)\end{array}$ & $\begin{array}{l}-4.234^{* * *} \\
(8.83)\end{array}$ & $\begin{array}{l}-2.392^{* * *} \\
(5.53)\end{array}$ \\
\hline Time & & & & $\begin{array}{l}-0.045^{* * *} \\
(24.65)\end{array}$ & $\begin{array}{l}-0.041^{* * *} \\
(21.63)\end{array}$ & \\
\hline FBond $\times$ Time & & & & $\begin{array}{l}0.008^{* * *} \\
(4.18)\end{array}$ & $\begin{array}{l}0.008^{* * *} \\
(3.98)\end{array}$ & \\
\hline Crisis & & & & & $\begin{array}{l}0.040^{* * *} \\
(7.91)\end{array}$ & \\
\hline FBond $\times$ Crisis & & & & & $\begin{array}{l}0.0005 \\
(0.06)\end{array}$ & \\
\hline Intercept & $\begin{array}{l}4.116^{* * *} \\
(44.92)\end{array}$ & $\begin{array}{l}5.569^{* * *} \\
(38.63)\end{array}$ & $\begin{array}{l}5.667^{* * *} \\
(17.22)\end{array}$ & $\begin{array}{l}5.312^{* * *} \\
(14.06)\end{array}$ & $\begin{array}{l}5.277^{* * *} \\
(14.30)\end{array}$ & $\begin{array}{l}5.818^{* * *}- \\
(17.69)\end{array}$ \\
\hline Fixed Effects & Year & Year & Firm/Year & Firm & Firm & Firm/Year \\
\hline Obs. & 3,015 & 2,357 & 2,357 & 2,357 & 2,357 & 2,357 \\
\hline Adj. $R^{2}$ & 0.673 & 0.721 & 0.850 & 0.775 & 0.786 & 0.852 \\
\hline
\end{tabular}




\section{Table 5 (continued)}

This table provides regression results for the sample of bond yields for U.S. railroads listed in New York and London from 1873 to 1913. The dependent variable Spread is the yield less the prevailing yield on British government bonds. Time is equal to the year less 1873. FBond is an indicator variable which equals to unity if the firm has a bond foreign listing in London in the year and zero otherwise. The fixed effect variables are defined as either Year (annual) fixed effects or firm fixed effects. We also include controls for OffGold (fixed effect for the pre-1879 period, when the U.S. dollar was not yet fixed against gold and the sterling pound, and interaction of pre-1879 period with Sterling) and ExDay for London bonds with coupon dates at the end of the calendar year. The last regression contains interaction variables for the years of 1870s (1873-80), 1880s, 1890s, and 1900s (including 1910-1913). The Crisis variable is taken from the annual default rates for U.S. railroads in Figure 1 by Giesecke, Longstaff, Schaefer, and Strebulaev (2011). It is meant to model the time-varying credit-market conditions in the United States. Other variables are defined in Table 3. The absolute value t-statistics are in parentheses. ${ }^{*},{ }^{* *}$, and ${ }^{* * *}$ denote statistical significance at the $10 \%$, $5 \%$, and $1 \%$ level, respectively. 
Table 6

Determinants of U.S. railroad bond cross-listings in London

\begin{tabular}{|c|c|c|c|c|}
\hline & (1) & (2) & (3) & (4) \\
\hline Asset Growth & $\begin{array}{l}1.233^{* * *} \\
(9.42)\end{array}$ & & $\begin{array}{l}1.186^{* * *} \\
(9.50)\end{array}$ & $\begin{array}{l}1.234^{* * *} \\
(9.89)\end{array}$ \\
\hline ROA & $\begin{array}{l}-2.287 \\
(0.20)\end{array}$ & & $\begin{array}{l}-2.572 \\
(0.24)\end{array}$ & $\begin{array}{l}-6.490 \\
(1.26)\end{array}$ \\
\hline Default & $\begin{array}{l}1.351 \\
(3.23)\end{array}$ & & $\begin{array}{l}1.095 \\
(1.94)\end{array}$ & $\begin{array}{l}1.136 \\
(2.05)\end{array}$ \\
\hline NYSE Listing & $\begin{array}{l}-1.063^{* * *} \\
(11.60)\end{array}$ & & $\begin{array}{l}-1.139^{* * *} \\
(12.69)\end{array}$ & $\begin{array}{l}-1.112^{* * *} \\
(11.49)\end{array}$ \\
\hline$\Delta$ Diff (New York - London) & & $\begin{array}{l}4.768^{* * *} \\
(12.38)\end{array}$ & $\begin{array}{l}4.472^{* * *} \\
(8.37)\end{array}$ & $\begin{array}{l}4.590^{* * *} \\
(8.09)\end{array}$ \\
\hline$\Delta$ Diff (U.S. - British) & & $\begin{array}{l}1.208 \\
(1.93)\end{array}$ & $\begin{array}{l}1.286 \\
(1.73)\end{array}$ & $\begin{array}{l}2.020^{*} \\
(3.22)\end{array}$ \\
\hline Crisis & & $\begin{array}{l}0.028 \\
(0.00)\end{array}$ & $\begin{array}{l}0.056 \\
(0.01)\end{array}$ & $\begin{array}{l}-0.160 \\
(0.09)\end{array}$ \\
\hline$\Delta \mathrm{GDP}(\mathrm{U} . \mathrm{S}.) / \mathrm{GDP}(\mathrm{U} . \mathrm{K})$. & & $\begin{array}{l}0.664 \\
(0.13)\end{array}$ & $\begin{array}{l}0.842 \\
(0.18)\end{array}$ & $\begin{array}{l}1.203 \\
(0.36)\end{array}$ \\
\hline Region_Track_Growth & & $\begin{array}{l}18.431^{* * *} \\
(11.80)\end{array}$ & $\begin{array}{l}14.672^{* *} \\
(5.87)\end{array}$ & $\begin{array}{l}13.015 \\
(4.38)\end{array}$ \\
\hline SW_1870s & & $\begin{array}{l}-1.401^{*} \\
(2.97)\end{array}$ & $\begin{array}{l}-1.785 \\
(2.63)\end{array}$ & $\begin{array}{l}-1.430 \\
(1.70)\end{array}$ \\
\hline Intercept & $\begin{array}{l}-3.554^{* * *} \\
(135.6)\end{array}$ & $\begin{array}{l}-23.23^{* * *} \\
(17.35)\end{array}$ & $\begin{array}{l}-18.589^{* * *} \\
(8.78)\end{array}$ & $\begin{array}{l}-16.69^{* * *} \\
(6.70)\end{array}$ \\
\hline Fixed effects & No & No & No & Firm \\
\hline Obs. & 3,318 & 3,538 & 3,239 & 3,239 \\
\hline
\end{tabular}

This table provides logistic regression results for the sample of bond listings for U.S. railroads listed in New York and London from 1873 to 1913 . The dependent variable is an indicator variable that equals one if the firm is listed in London during that year. Time is equal to the year less 1873. The NYSE Listing variable is equal to one if the firm is listed in New York during the previous year. $\Delta$ Diff (New York - London) is the change in the annual New York less London yield difference from Table 4. $\Delta$ Diff (U.S. - British) is the average annual difference between U.S. and British railroad bond yields listed in London from Table 4. The Crisis variable is taken from the annual default rates for U.S. railroads in Figure 1 by Giesecke, Longstaff, Schaefer, and Strebulaev (2011). $\Delta$ GDP(U.S.)/GDP(U.K.) is the annual change in the GDP of the United States divided by the GDP of the United Kingdom. Region_Track_Growth is the annual change in the annual growth rate in the total mileage of all railroad tracks in a given U.S. region. SW_1870s is an indicator variable that equals one for U.S. railroads originating from the SOUTH and WEST regions in the 1870s, and is zero otherwise. Other variables are defined in Table 3. All independent variables have been lagged in these tests by one year. The Wald chi-square statistic for the coefficient is reported in parentheses. ${ }^{*},{ }^{* *}$, and ${ }^{* * *}$ denote statistical significance at the $10 \%, 5 \%$, and $1 \%$ level, respectively. 
Table 7

Summary statistics for matched bonds across U.S. regions

Panel A: Bond yield spreads across regions

\begin{tabular}{llllll}
\hline & ALL & NORTH & CENTRAL & SOUTH & WEST \\
\hline Obs. & 848 & 187 & 207 & 168 & 286 \\
$\begin{array}{l}\text { New York } \\
\quad \text { Mean }\end{array}$ & & & & & \\
$\quad$ Median & 1.740 & 1.470 & 1.584 & 1.897 & 1.937 \\
$\quad$ London & 1.594 & 1.304 & 1.657 & 1.906 & 1.700 \\
$\quad$ Mean & & & & & \\
$\quad$ Median & 1.694 & 1.457 & 1.564 & 1.842 & 1.854 \\
$\quad$ Diff (New York - London) & 1.550 & 1.342 & 1.602 & 1.760 & 1.633 \\
& $0.047^{* * *}$ & $0.013^{*}$ & $0.020^{* * *}$ & $0.055^{* *}$ & $0.083^{* * *}$ \\
& $(13.06)$ & $(1.86)$ & $(2.98)$ & $(7.81)$ & $(11.12)$ \\
\hline
\end{tabular}

Panel B: Regional bond yield spread differences over time

\begin{tabular}{|c|c|c|c|c|}
\hline & $1880 \mathrm{~s}$ & $1890 \mathrm{~s}$ & $1900 \mathrm{~s}$ & $1900 s-1880 s$ \\
\hline \multicolumn{5}{|l|}{ ALL } \\
\hline Obs. & 169 & 327 & 346 & \\
\hline Mean & 0.076 & 0.037 & 0.036 & $\begin{array}{l}-0.040^{* * *} \\
(3.00)\end{array}$ \\
\hline \multicolumn{5}{|l|}{ NORTH } \\
\hline Obs. & 27 & 69 & 91 & \\
\hline Mean & 0.088 & -0.007 & 0.005 & $\begin{array}{l}-0.083^{* * *} \\
(3.79)\end{array}$ \\
\hline \multicolumn{5}{|l|}{ CENTRAL } \\
\hline Obs. & 55 & 80 & 72 & \\
\hline Mean & 0.064 & -0.004 & 0.012 & $\begin{array}{l}-0.052^{* * *} \\
(2.90)\end{array}$ \\
\hline \multicolumn{5}{|l|}{ SOUTH } \\
\hline Obs. & 34 & 79 & 55 & \\
\hline Mean & 0.070 & 0.053 & 0.047 & $\begin{array}{l}-0.023 \\
(1.36)\end{array}$ \\
\hline \multicolumn{5}{|l|}{ WEST } \\
\hline Obs. & 59 & 99 & 128 & \\
\hline Mean & 0.108 & 0.090 & 0.067 & $\begin{array}{l}-0.041 \\
(1.58)\end{array}$ \\
\hline Diff (CENTRAL - NORTH) & $\begin{array}{l}-0.024 \\
(0.97)\end{array}$ & $\begin{array}{l}0.003 \\
(0.18)\end{array}$ & $\begin{array}{l}0.007 \\
(0.52)\end{array}$ & \\
\hline Diff (SOUTH - NORTH) & $\begin{array}{l}-0.018 \\
(0.79)\end{array}$ & $\begin{array}{l}0.060^{* * *} \\
(3.96)\end{array}$ & $\begin{array}{l}0.042^{* * *} \\
(2.80)\end{array}$ & \\
\hline Diff (WEST - NORTH) & $\begin{array}{l}0.020 \\
(0.70)\end{array}$ & $\begin{array}{l}0.096^{* * *} \\
(5.87)\end{array}$ & $\begin{array}{l}0.062^{* * *} \\
(5.21)\end{array}$ & \\
\hline
\end{tabular}




\section{Table 7 (continued)}

This table provides the summary statistics for the difference in New York and London yield spreads for the matched bond sample of U.S. railroads from 1875 to 1913 across regions. The U.S. regions are defined in Table 1. Panel A reports the number of firms that maintain bond listings in both New York and London, their number of observations, the respective mean and median bond yields in percentage points. Diff (New York - London) is the difference in mean bond yields with the corresponding absolute t-statistics. Panel B reports the summary statistics of bond yield spread differences across U.S. regions by decade. $1900 \mathrm{~s}-1880 \mathrm{~s}$ is a test of the difference in matched bond means for each region between 1900s and 1880s and its absolute t-statistic. Diff (CENTRAL - NORTH), Diff (SOUTH - NORTH), and Diff (WEST - NORTH) indicate the difference in means tests between the CENTRAL, SOUTH, and WEST regions, respectively, and NORTH with the corresponding absolute t-statistics. ${ }^{*},{ }^{* *}$, and ${ }^{* * *}$ denote statistical significance at the $10 \%, 5 \%$, and $1 \%$ level, respectively. 
Table 8

Aggregate regression estimates: Regional bond yield spread differences for matched bonds

\begin{tabular}{|c|c|c|c|c|}
\hline & $(1)$ & $(2)$ & (3) & (4) \\
\hline CENTRAL & $\begin{array}{l}0.006 \\
(0.60)\end{array}$ & $\begin{array}{l}0.021 \\
(0.71)\end{array}$ & & \\
\hline SOUTH & $\begin{array}{l}0.030^{* * *} \\
(2.70)\end{array}$ & $\begin{array}{l}0.021 \\
(0.71)\end{array}$ & & \\
\hline WEST & $\begin{array}{l}0.047^{* * *} \\
(4.98)\end{array}$ & $\begin{array}{l}-0.044 \\
(1.35)\end{array}$ & & \\
\hline Time & & $\begin{array}{l}-3.200^{* * *} \\
(3.72)\end{array}$ & & $\begin{array}{l}-1.380^{* *} \\
(2.31)\end{array}$ \\
\hline CENTRAL $\times$ Time & & $\begin{array}{l}-1.120 \\
(0.95)\end{array}$ & & \\
\hline SOUTH $\times$ Time & & $\begin{array}{l}2.622^{* *} \\
(2.03)\end{array}$ & & \\
\hline WEST $\times$ Time & & $\begin{array}{l}0.115 \\
(0.11)\end{array}$ & & \\
\hline Distance & & & $\begin{array}{l}0.028^{* * *} \\
(5.32)\end{array}$ & $\begin{array}{l}0.070^{* * *} \\
(5.84)\end{array}$ \\
\hline Distance $\times$ Time & & & & $\begin{array}{l}-1.490^{* * *} \\
(3.20)\end{array}$ \\
\hline Years-to-Maturity & $\begin{array}{l}0.787^{* * *} \\
(6.00)\end{array}$ & $\begin{array}{l}0.583^{* * *} \\
(4.34)\end{array}$ & $\begin{array}{l}0.931^{* * *} \\
(7.13)\end{array}$ & $\begin{array}{l}0.755^{* * *} \\
(5.69)\end{array}$ \\
\hline Default & $\begin{array}{l}0.036 \\
(1.18)\end{array}$ & $\begin{array}{l}0.024 \\
(0.77)\end{array}$ & $\begin{array}{l}0.048 \\
(1.57)\end{array}$ & $\begin{array}{l}0.039 \\
(1.28)\end{array}$ \\
\hline Intercept & $\begin{array}{l}-0.021 \\
(0.93)\end{array}$ & $\begin{array}{l}0.092^{* * *} \\
(3.83)\end{array}$ & $\begin{array}{l}-0.024 \\
(1.08)\end{array}$ & $\begin{array}{l}0.030^{*} \\
(1.77)\end{array}$ \\
\hline Fixed Effects & Year/Ex-Day & Ex-Day & Year/Ex-Day & Ex-Day \\
\hline Obs. & 848 & 848 & 848 & 848 \\
\hline Adj. $R^{2}$ & 0.227 & 0.159 & 0.225 & 0.165 \\
\hline
\end{tabular}

This table provides regression results for the difference in New York and London yield spreads of the matched bond sample of U.S. railroads from 1875 to 1913. The U.S. regions are defined in Table 1. The dependent variable is the end-of-year difference in the prevailing yield between each pair of New York and London listed bonds. Time is the number of years since 1875. Distance is defined as the distance in 1000s of miles between New York City and the location of the railroad's Principal Office. Ex-Day captures a fixed effect for London bonds with coupon dates at the end of the calendar year. The coefficients on Time are multiplied by 1,000. The absolute t-statistics are in parentheses. ${ }^{*},{ }^{* *}$, and ${ }^{* * *}$ denote statistical significance at the $10 \%, 5 \%$, and $1 \%$ level, respectively. 


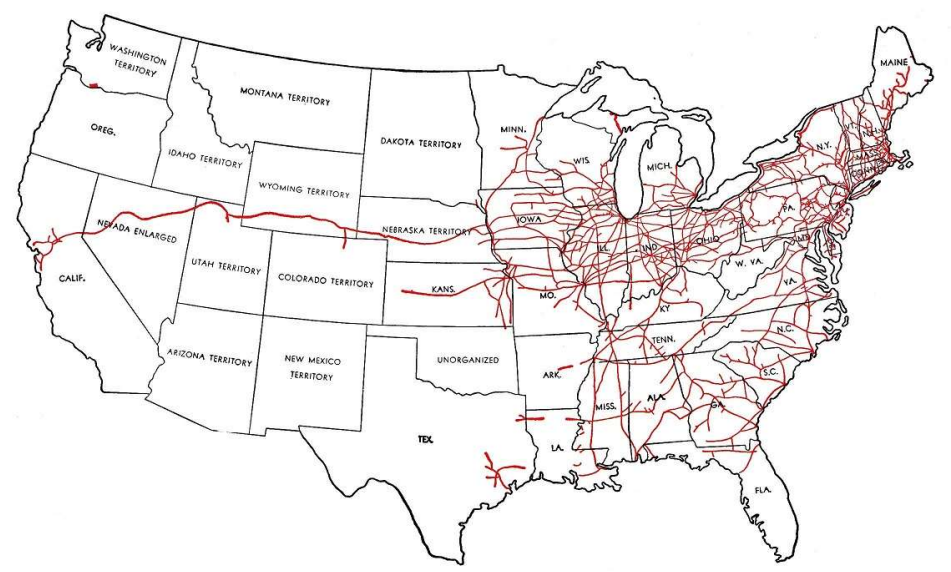

Plot A: 1870

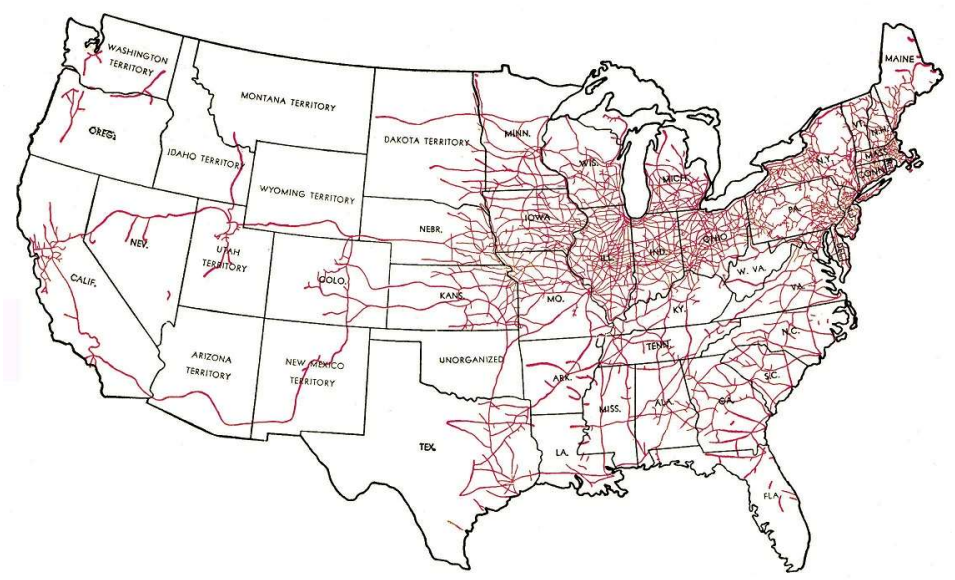

Plot B: 1880

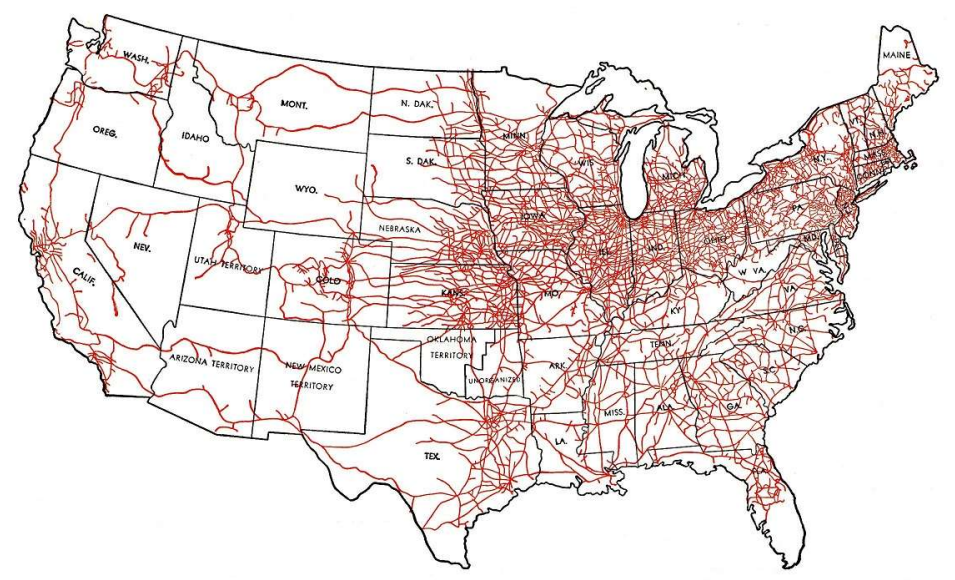

Plot C: 1890

Figure 1. Historical railroad maps of the United States. This figure shows the U.S. railroad maps in 1870 (Plot A), 1880 (Plot B), and 1890 (Plot C). The source: "American Railroads: Their Growth and Development," The Association of American Railroads, 1951. http://www.cprr.org/Museum/RR_Development.html. 


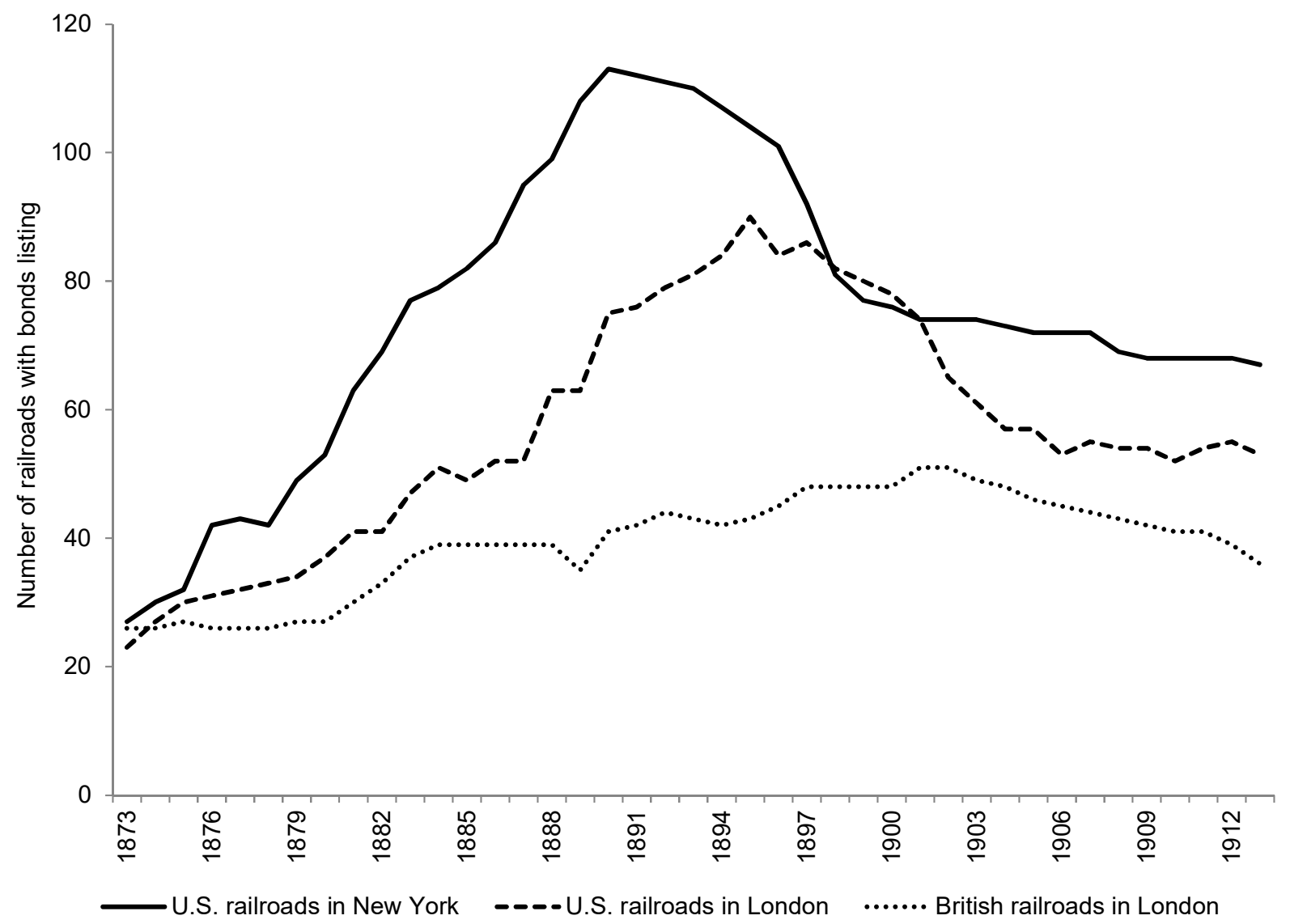

Figure 2. Frequency of railroad bonds listed in London and New York. This figure shows the number of U.S. railroads with bonds listed in each of New York and London, and the number of British railroads with bonds listed in London for each year between 1873 and 1913. 


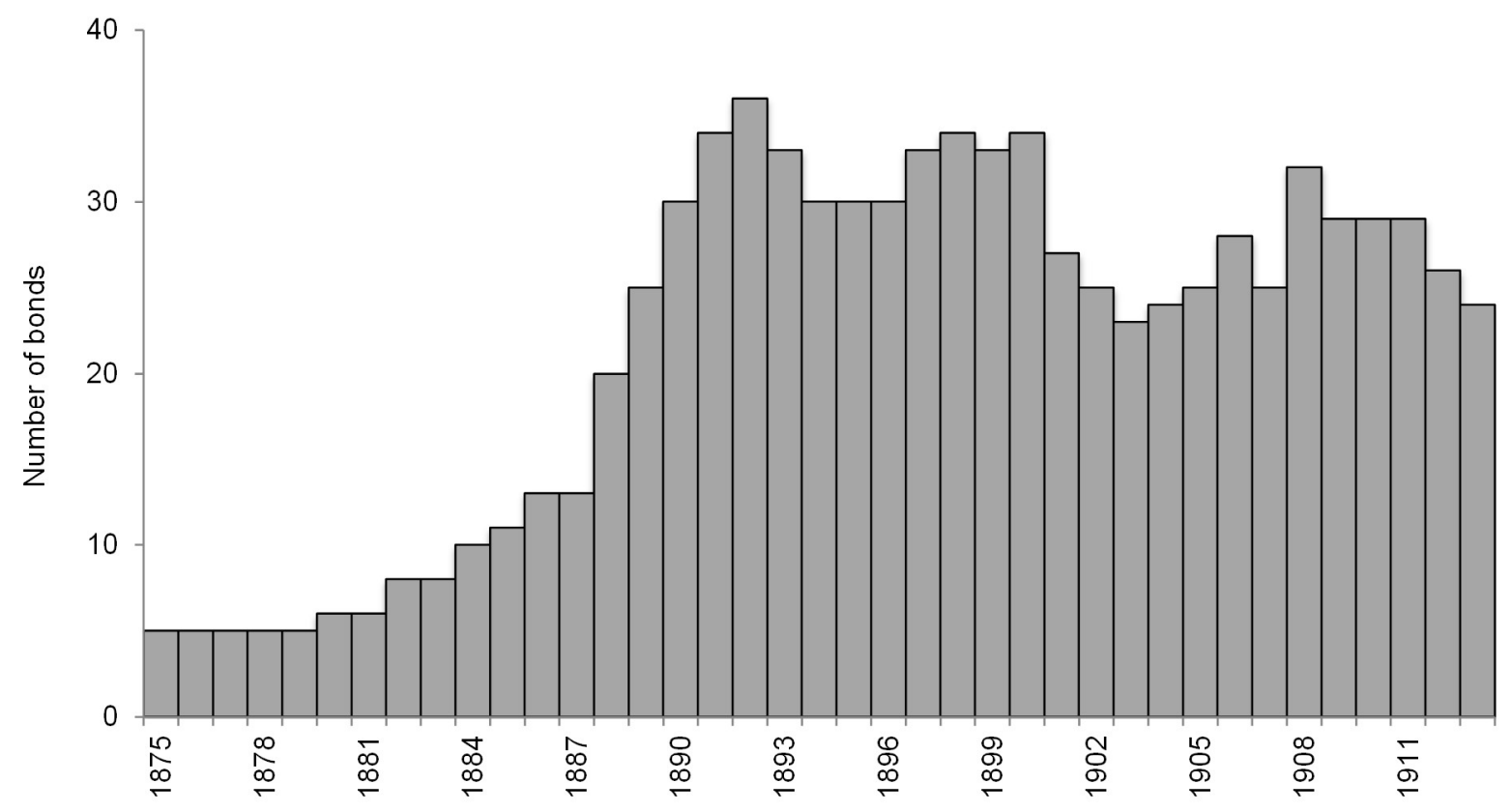

Plot A: Frequency distribution of the number of bonds traded in both New York and London

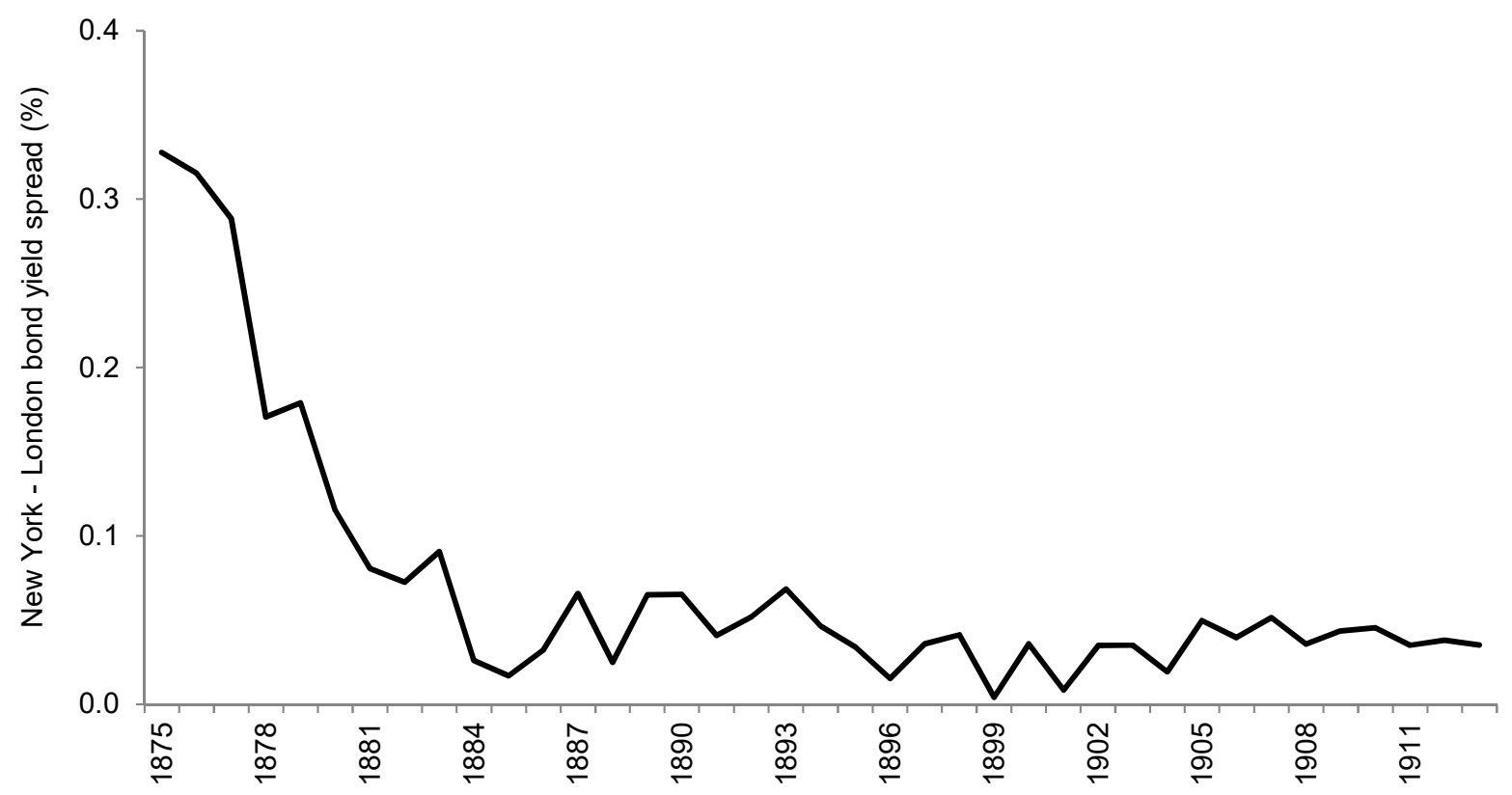

Plot B: New York - London mean difference in bond yields

Figure 3. Matched bonds listed in both New York and London. This figure shows the number of bonds and the difference in the yield of identical bonds traded contemporaneously in both New York and London between 1879 and 1913 for the sample of 45 railroads. Plot A gives the yearly frequency distribution of the number of such bonds traded in both cities. Plot B shows the corresponding difference (in percent) between New York and London bond yield spreads over the sample period covering more than two bond yield observations. 


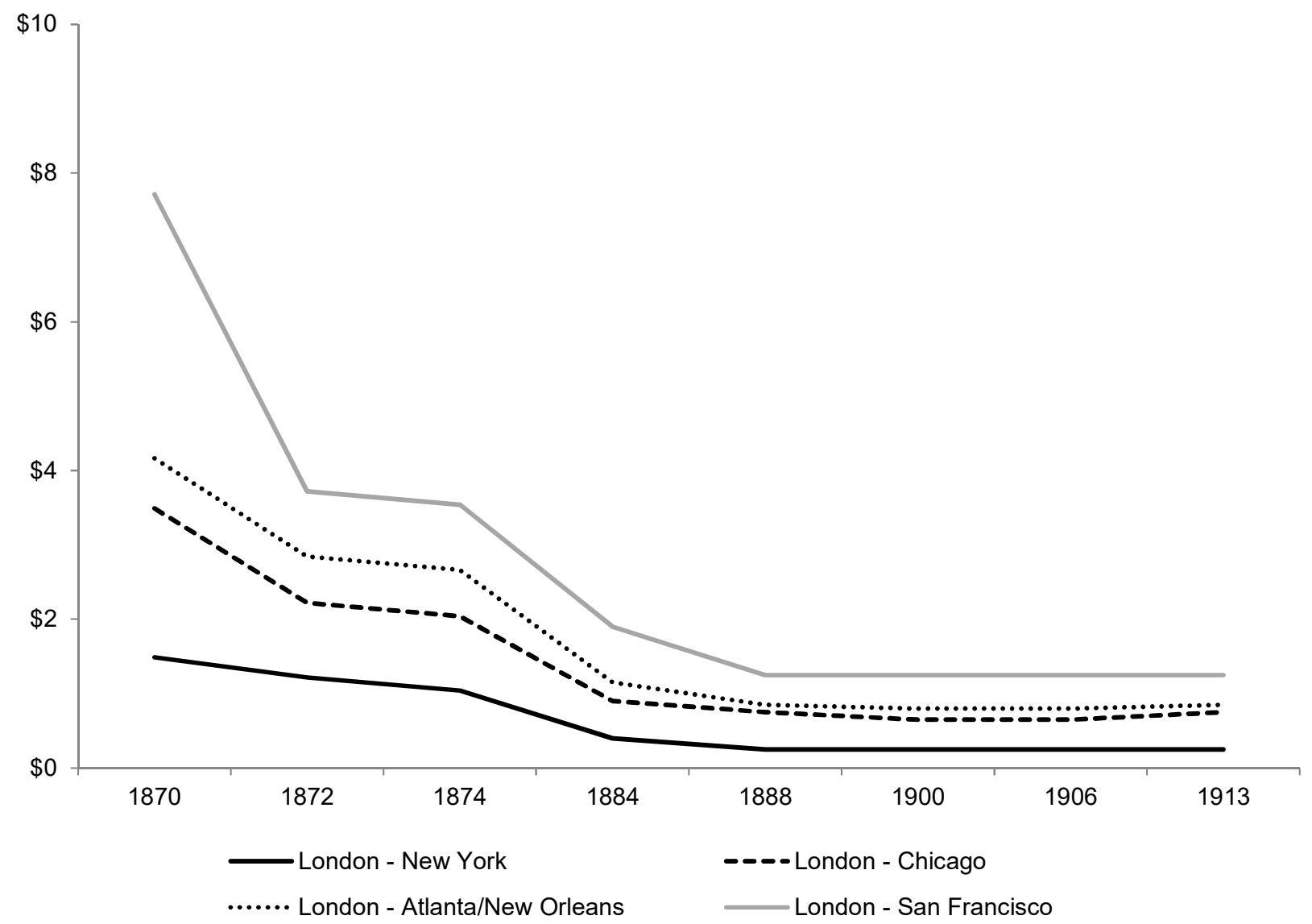

Figure 4. Telegraph communication rates from London by destination city. This figure shows the telegraph communication rates from London to the centers of four U.S. regions. Rates are the cost of transmitting the first 10 words of any message. The source data for London to New York is published in the Historical Statistics of the United States: Colonial Times to 1970 Part 2, U.S. Department of Commerce, 1975, based on documents from the U.S. Federal Communications Commission and other sources specified in the report. The rates from New York to Chicago, San Francisco, and the average of the rates from New York to Atlanta and New Orleans are from Honsowetz (2014). The rates from London to Chicago and to San Francisco and the average of the rates from London to Atlanta and New Orleans are estimated by adding the London - New York rate to the rate between the destination city and New York. Data points between some observations are interpolated. 